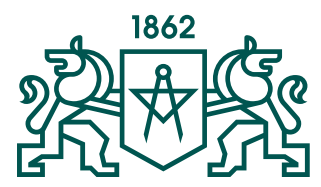

RĪGAS TEHNISKĀ UNIVERSITĀTE

\title{
Irēna Vaivode
}

UZṆĒMĒJDOMĀŠANAS ATTĪSTĪBA

KĀ VIRZOŠAIS FAKTORS VEIKSMĪGAS

"BORN GLOBAL" STRATĒG̣IJAS IZVEIDEI

Promocijas darba kopsavilkums

(बन

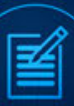

(C)

2.

$2 x^{2}$
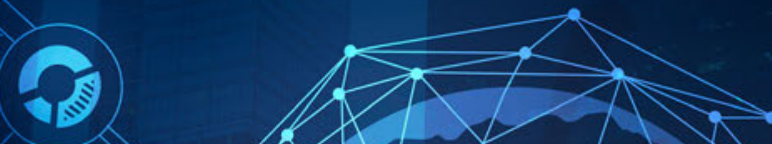


\title{
RĪGAS TEHNISKĀ UNIVERSITĀTE
}

Inženierekonomikas un vadības fakultāte

Uzṇēmējdarbības inženierijas un vadības institūts

\section{Irēna Vaivode}

Doktora studiju programmas "Vadībzinātne un ekonomika" doktorante

\section{UZṆĒMĒJDOMĀŠANAS ATTĪSTĪBA KĀ VIRZOŠAIS FAKTORS VEIKSMĪGAS "BORN GLOBAL" STRATĒG̣IJAS IZVEIDEI}

Promocijas darba kopsavilkums

\author{
Zinātniskais vadītājs \\ asociētais profesors Dr. oec. \\ DENISS ŠČEULOVS
}


Vaivode I. Uzṇēmējdomāšanas attīstība kā virzošais faktors veiksmīgas

"born global" stratēgijas izveidei. Promocijas darba kopsavilkums. -

Rīga: RTU Izdevniecíba, 2021. - 26 lpp.

Iespiests saskaṇā ar promocijas padomes “RTU P-09” 2021. gada

24. septembra lēmumu, protokols Nr. 04030-9.9.1/5.

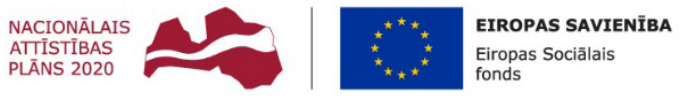

I E G ULDİJUMS TA V Ā N $\bar{A} K$ OTN $\bar{E}$

Promocijas darbs izstrādāts ar Eiropas Sociālā fonda projekta "Rīgas Tehniskās universitātes akadēmiskā personāla stiprināšana stratēǵiskās specializācijas jomās” 8.2.2.0/18/A/017 (SAM 8.2.2.) atbalstu. 


\title{
PROMOCIJAS DARBS IZVIRZĪTS ZINĀTNES DOKTORA GRĀDA IEGŪŠANAI RĪGAS TEHNISKAJĀ UNIVERSITĀTE
}

Promocijas darbs zinātnes doktora $(P h$. D.) grāda iegūšanai tiek publiski aizstāvēts 2022. gada 14. janvārī plkst. 12.00 Rīgas Tehniskās universitātes promocijas padomes atklātajā sēdē tiešsaistē platformā Zoom.

\author{
OFICIĀLIE RECENZENTI \\ Profesore Dr. oec. Natalja Lāce, \\ Rīgas Tehniskā universitāte \\ Profesore Dr. oec. Jel̦ena Titko, \\ Ekonomikas un kultūras augstskola, Latvija \\ Profesore Dr. Renata Korsakienè \\ Viḷnas Ģedimina Tehniskā universitāte, Lietuva
}

\section{APSTIPRINĀJUMS}

Apstiprinu, ka esmu izstrādājusi šo promocijas darbu, kas iesniegts izskatǐšanai Rīgas Tehniskajā universitātē zinātnes doktora $(P h . D$.) grāda iegūšanai. Promocijas darbs zinātniskā grāda iegūšanai nav iesniegts nevienā citā universitātē.

Irēna Vaivode

Datums:

Promocijas darbs ir uzrakstīts angḷu valodā, tajā ir ievads, trīs daḷas, secinājumi un priekšlikumi, literatūras saraksts, 45 attēli, 46 tabulas, kopā 150 lappušu, neieskaitot pielikumus. Literatūras sarakstā ir 284 nosaukumi. 


\section{SATURS}

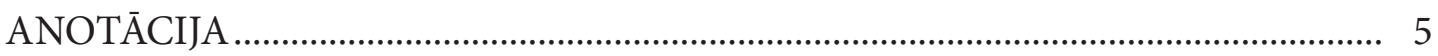

DARBA VISPĀRĒJS RAKSTUROJUMS ................................................................... 6

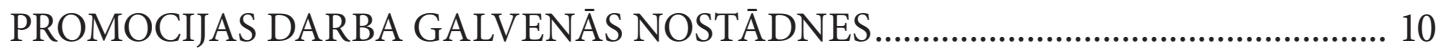

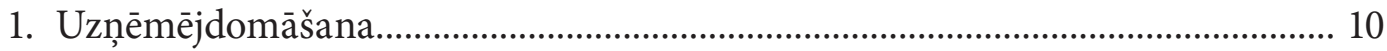

2. Saistība starp uzṇēmējdomāšanu un "born global” fenomenu............................. 12

3. Saistība starp uzṇēmējdomāšanu un "born global” stratēǵiju .............................. 14

4. Uzñēmējdomāšanu veidojošo faktoru analīze ....................................................... 16

5. Metodika uzṇēmējdomāšanas virzǐšanai uz "born global”................................... 21

PROMOCIJAS DARBA GALVENIE SECINĀJUMI UN PRIEKŠLIKUMI ................. 22

AUTORES PUBLIKĀCIJAS PAR PROMOCIJAS DARBA TĒMU................................ 24 


\section{ANOTĀCIJA}

Promocijas darbs ir uzrakstīts angḷu valodā, tajā ir ievads, trīs galvenās daḷas, secinājumi un ieteikumi. Promocijas darba pamatteksts ir izklāstīts 150 lappusēs un ietver 45 attēlus un 46 tabulas. Promocijas darbam ir pielikumi. Bibliogrāfijā ir iekl̦auti 284 literatūras avoti.

Promocijas darba tēma ir klasificējama kā pētījums uzṇēmējdomāšanas jomā. Tajā tiek pētīta uzñēmējdomāšanas un veiksmīgas "born global” stratēgijas izveides procesa mijiedarbība. Zīmols "born global” $(B G)$ atspoguḷo jaunu paradigmu pasaules ekonomikā; šo uzṇēmumu rašanās liecina par pasaules ekonomikas daudzveidību, ir veicinošs faktors valstu ekonomikas attīstībai, stimulējot inovāciju rašanos, sniedzot jaunas prasmes un zināšanas, atbalstot ražošanas tempu pieaugumu un veicinot produktu ar augstu pievienoto vērtību radīšanu. Uzņēmējam ir centrālā loma “born global” uzṇēmumu veidošanas procesā.

Uzṇēmējdomāšana ir promocijas darba pētījuma objekts, tā tiek pētīta kā dinamisks process, kas virza indivīdu uz konkrētu rezultātu sasniegšanu. Veiksmīgas “born global” stratēgijas izveidi var uzskatīt par uzṇēmējdomāšanas dinamiskā procesa rezultātu.

Promocijas darbs ietver pētījumus par uzṇēmējdomāšanas raksturlielumu līmeņa lomu kā pamatu uzṇēmēja virzībai uz veiksmīgu "born global” procesu.

Promocijas darba pētījuma mērḳis ir izpētīt uzṇēmējdomāšanas kā dinamiska procesa teorētiskos aspektus un tā mijiedarbību ar "born global” fenomenu; izstrādāt un aprobēt metodiku, kuras mērķis ir veicināt uzṇēmējdomāšanas kā virzìtājspēka veiksmīgas “born global” stratēgijas izveidei, attīstību.

Promocijas darba pirmajā daḷā autore izveidojusi teorētisko pamatu, lai nodrošinātu pētījuma mērķa sasniegšanu. Veikta mijiedarbības starp uzņēmējdomāšanu un veiksmīgas “born global” stratēgijas izveidi teorētiskā analīze. Uzṇēmējdomāšana tiek analizēta, pamatojoties uz individuālajiem raksturlielumiem, kuru teorētiskais pamatojums rodams kauzācijas un izpildes teorijās. Abas minētās teorijas ir izvēlētas kā darba teorētiskais un zinātniskais pamats, lai radītu izpratni par veidu, kā uzṇēmēji iesaistās plānošanas aktivitātes un veido "born global” stratēgijas.

Empīriskais pētījums darba otrajā daḷā ietver aptaujas anketā iekḷauto jautājumu skaidrojumu, rezultātu analīzes metožu aprakstu, pētījuma rezultātu analīzi ar kvalitatīvās salīdzinošās analīzes ( $\left.f_{s} Q C A\right)$ metodi, aptaujas rezultātu pamatojumu, balstoties ekspertu koncepcijās. FsQCA analīzes metode izmantota, lai pētītu saistību starp uzṇēmējdomāšanas individuālo rakstulielumu līmeni un gala lēmumu pieņemšanas loǵiku, balstītu kauzācijas un izpildes teorijās. Aptaujas rezultāti ir pamatoti ar eksperta koncepciju, balstītu Koila (Coyle’s) izstrādātajā uzṇēmējdomāšanas "sešu īpašibu” modelī.

Trešā daḷa veltīta uzṇēmējdomāšanas attīstības metodologijas izveidei un ieviešanai, kas ir pamatā veiksmīgas "born global” stratēgijas izstrādei. Metodikai ir divi posmi: (1) metodika topošā uzṇēmēja gatavības pakāpes darboties globālajā tirgū novērtēšanai; (2) metodika uzñēmējdomāšanas virzībai uz "born global”. Otrā posma mērḳis ir atvieglot topošo uzņēmēju sagatavošanas procesu virzībai uz starptautisko tirgu un viṇu gatavību būt konkurētspējīgiem biznesa izaugsmes un brieduma posmos, izstrādāt veiksmīgu "born global” stratēǵiju. Uzṇēmējdomāšanas attīstības metodika, kas ḷauj veidot veiksmīgu "born global” stratēgiju, ir balstīta esošajā veiksmīgu ārvalstu biznesa inkubatoru pieredzē. Metodikas aprobācija nodrošināta sadarbībā ar LIAA biznesa inkubatoriem, galvenokārt sadarbībā ar Siguldas biznesa inkubatoru.

Atslēgvārdi: “born global” uzṇēmums, "born global” uzṇēmuma definīcija, kauzācijas un izpildes teorijas, konkurētspējīga stratēgija, uzṇēmējdomāšana, ienākšanas tirgū stratēgija, metodika, riska uztvere, pašefektivitāte, sistēmiskā pieeja startēgijas izveidei. 


\section{DARBA VISPĀRĒJS RAKSTUROJUMS}

\section{Promocijas darba aktualitāte}

Uzņēmējsabiedrības attīstība kā mūsdienu tendence mudina arvien vairāk valstīm pieņemt uzņēmējdarbību par svarīgu ekonomikas dzinējspēku un galveno inovāciju un darba vietu radīšanas avotu. Mazie un vidējie uzņēmumi (MVU) mūsdienās tiek uzskatīti par ekonomikas izaugsmes virzītājiem, tiem ir galvenā loma nodarbinātības iespēju radī̌̌anā, produktu ar pievienoto vērtību ražošanā un inovāciju ieviešanā. Pasaules valstu valdỉbas veicina inovāciju rašanos mazo un vidējo uzņēmumu nozarē kā uzṇēmējdarbības potenciālu, tādējādi attīstītot šo valstu ekonomiku. Politikas veidotāji ir ieinteresēti veicināt un paātrināt jaunizveidoto uzņēmumu eksporta iespējas, lai stimulētu ekonomisko izaugsmi un jaunu darba vietu radīšanu. Šie uzņēmumi arvien vairāk ienāk starptautiskajos tirgos, lai izmantotu savu inovatīvo produktu un pakalpojumu potenciālu plašāk, cenšas pielāgoties starptautiskajiem tirgiem, lai konkurētu, augtu un izdzīvotu. Jaunuzņēmumu dibinātāji aizvien vairāk ir ieinteresēti darboties globālajos tirgos, un tā rezultātā arī ir radies fenomens pasaules ekonomikā, ko pazīstam kā "born global” (BG) uzṇēmumus, kas gāž tradicionālos uzskatus par uzṇēmumu internacionalizācijas procesu, kad starptautiskajā biznesā ilgu laiku dominēja tikai lieli starpnacionāli uzṇēmumi, kuru rīcībā ir milzīgi resursi. Arvien vairāk jaunu uzṇēmumu uzskata sevi par "born global”. Atšķirībā no tradicionālā uzṇēmumu internacionalizācijas ceḷa, kur galvenais darbības virziens vispirms tiek vērsts uz konkrētās valsts vietējo tirgu, šie jaunie uzṇēmumi jau iesākumā konkurē globālajā tirgū. Uzṇēmumi apkalpo klientus visā pasaulē, piedāvājot jaunas, novatoriskas preces un pakalpojumus un ḷoti bieži darbojas kā spēles noteikumu mainītāji attiecīgajās nozarēs. "Born global” kā parādība, kuras nozīme arvien palielinās, pēdējos gados ir strauji augusi un patlaban uzṇem apgriezienus. L̦oti bieži “born global” uzņēmumi rada pilnīgi jaunu tirgu. Tas notiek, vai nu radot pavisam jaunas idejas, vai arī izveidojot jaunas tirgus nišas, kurās tiek integrētas esošās idejas, rodot tām jaunus risinājumus. Šāda stratēgija parasti nozīmē gatavību uzņemties papildu riskus, cenšanos panākt straujāku izaugsmi, izmantojot nepieciešamos un konkrētajā brīdī pieejamos resursus, ātri pielāgojoties jauniem tirgiem, attīstīstot vadības prasmes.

"Born global” fenomens galveno uzsvaru liek uz individuālo uzṇēmēju pretēji organizācijai, stratēgijām un vadības lēmumu pieṇemšanas veidam, kas raksturīgs labi izveidotajiem daudznacionālajiem uzṇēmumiem. "Born global” uzṇēmēji balstās uz zināšanām, kuru pamatā ir indivīda iepriekšējā pieredze un kas palīdz atklāt un īstenot jaunas uzṇēmējdarbības iespējas. Globalizācijas spēki rada tirgus iespējas un konkurences izaicinājumus jauniem uzņēmumiem. Sadarbības tīklu veidošana tiek uzskatīta par veidu, kā iegūt jaunas zināšanas par starptautiskajiem tirgiem, tā veicina piekḷuvi starptautiskajām stratēgiskajām aliansēm un palīdz veidot attiecības gan ar maziem uzṇēmumiem, gan lieliem ārvalstu piegādātāiiem.

Ir vairāki piemēri, kas ilustrē pieaugošo "born global” nozīmi Eiropā.

- Zviedrija ir vērsusi uzmanību uz "born global” nozīmību valdības līmenī. 2016. gadā Zviedrijas valdība publicēja eksporta stratēóiju, kurā īpaši uzsvērts, cik svarīgi ir veicināt "born global” uzņēmumu rašanos. Daudzi no Zviedrijas redzamākajiem piemēriem ir informācijas tehnologiju jomā, piemēram, Skype, Spotify un Mojang (Minecraft izstrādātājs).

- Dānijas “born global” uzṇēmumi tiek plaši apspriesti, un šajā valstī to skaitam ir augšupejoša tendence.

- Viens no spilgtākajiem piemēriem Eiropā ir Austrijas “born global” uzṇēmumi. Austrijas Federālā ekonomikas palāta katru gadu jaunajiem Austrijas uzṇēmumiem pieškir balvu "Born global čempioni”. 2020. gadā šĩs balvas tika pasniegtas 30 nesen dibinātiem Austrijas uzṇēmumiem. Austrijas kā mazas valsts panākumus šajā jomā raksturo tālāk sniegtā informācija.

“Born global čempionu” balvas ir saṇēmuši jaunizveidotie uzṇēmumi, kas jau iesākumā ir balstījušies uz virzību globālajā tirgū, piedāvājot inovatīvus produktus un pakalpojumus un panākot strauju starptautisku izaugsmi. Balvu ieguvēji ir drosmīgi, domā pozitīvi un zina, ka visa pasaule ir viņu tir- 
gus - un tas ir viņu panākumu noslēpums. Tas arī liecina par gatavību uzņemties papildu risku, lai panāktu ātrāku izaugsmi, kā arī nepieciešamo un esošo resursu prasmīgu lietojumu, lai ātri pielāgotos starptautiskajiem tirgiem. Visiem balvas ieguvējiem ir viena kopīga iezīme: viņi diktē spēles noteikumus savā jomā un veicina Austrijas kā viṇu uzṇēmējdarbības izcelsmes valsts atpazīstamību ar saviem izcilajiem un novatoriskajiem sasniegumiem.

Lai sasniegtu darbā formulēto mērḳi, tika izvirzìti vairāki pētījuma uzdevumi.

1. Izpētīt uzṇēmējdomāšanas lomu "born global” uzṇēmuma izveides procesā un veiksmīgas "born global” stratēgiijas lietošanā. Šo izpēti veikt, izmantojot monogrāfiskās dokumentu analīzes metodi kā vispāratzītu kvalitatīvu pētījumu metodi, kas balstīta plašā zinātniskās literatūras apskatā.

2. Identificēt uzṇēmējdomāšanas individuālos raksturlielumus, kas virza uzṇēmēja lēmumu pieņemšanas procesu. Lai sasniegtu šo mērķi, izmantot zinātniskās literatūras pārskatu.

3. Lai atklātu saikni starp uzn̦ēmējdomāšanu, "born global” fenomenu un veiksmīgas "born global” stratēgijas izveidi, balstoties zinātniskās literatūras pārskatā, definēt pētījuma hipotēzi.

4. Veikt empīrisko pētījumu, lai noskaidrotu uzṇēmējdomāšanas individuālo raksturlielumu iezīmes, kas virza uzṇēmēju uz plānotajām aktivitātēm un konkrētu rezultātu. Izmantot aptauju kā empīriskā pētījumu metodi, iegūstot informāciju no topošajiem uzṇēmējiem, aicinot viṇus atbildēt uz anketas jautājumiem. Datu analīzei kā statistiskās izpētes metodi izmantot kvalitatīvo salīdzinošās analīzes metodi $\left(f_{s} Q C A\right)$.

5. Izstrādāt metodiku, kas palīdzētu noteikt topošā uzṇēmēja gatavības pakāpi būt "born global”, kā arī apmācības programmās balstītu metodiku, kas palīdzētu virzìt uzṇēmējdomāšanas attīstību veiksmīgas "born global” stratēgijas izstrādes virzienā.

6. Nodrošināt jaunizveidotās metodikas aprobāciju sadarbībā ar biznesa inkubatoriem, iekḷaujot biznesa inkubatoru direktorus kā šì procesa ekspertus.

\section{Pētijuma mērksis}

Izpētīt uzņēmējdomāšanas kā dinamiska procesa teorētiskos aspektus un tā mijiedarbību ar “born global" fenomenu; izstrādāt un apstiprināt metodiku, kas palīdzētu pilnveidot uzṇēmējdomāšanu kā virzìtājspēku veiksmīgas "born global” stratēgijas izveidei.

Pētījuma objekts ir uzṇēmējdomāšana.

Pētījuma priekšmets ir "born global” stratēgijas izstrāde.

\section{Pētijuma hipotēze}

Uzṇēmējdomāšanas individuālie raksturlielumi ir galvenie faktori, kuros tiek balstīts uzṇēmēja domāšanas veids, tie virza uzṇēmēju uz konkrētām biznesa aktivitātēm un plānoto rezultātu sasniegšanu.

\section{Promocijas darbā izmantotās metodes}

Lai veiksmīgi sasniegtu pètījuma mērḳi un izpildītu definētos uzdevumus, autore izmantoja tādas vispārzināmas kvantitatīvās un kvalitatīvās pētījumu metodes sociālajās zinātnēs kā:

- monogrāfiska dokumentu analīzes metode, kas paredzēta, lai veiktu detalizētu pètījuma objekta izpēti, pamatojoties uz plašu zinātniskās literatūras apskatu;

- statistikas izpētes metode; autore kā kvalitatīvās salīdzinošās analīzes $(Q C A)$ metodes konfigurāciju izmantoja neskaidras kopas kvalitatīvu salīdzinošo analīzi $\left(f_{s} Q C A\right)$;

- intervijas metode; ekspertu intervijas, lai uzzinātu ekspertu viedokli par BG fenomena būtību un viņu pieeju $B G$ definīcijas izpratnei, kā arī viedokli par nepieciešamību veicināt uzṇēmējdomāšanu kā virzìtājspēku veiksmīgas $B G$ stratēǵijas izstrādei; 
- aptauja; empīriskā metode ekonomisko un sociālo pētījumu jomā, kuras rezultātā informācija tika iegūta no aptuveni 800 uzṇēmumiem Baltijas valstīs; dati tika vākti tiešsaitē, izmantojot aptaujas anketu.

\section{Promocijas darba teorētiskais un metodiskais pamats}

Zinātniskās literatūras analīze tiek izmantota kā teorētiskā un metodiskā bāze, šim nolūkam izmantoti zinātnisko konferenču un semināru materiāli, ES un LR normatīvie dokumenti, Eurostat un citu starptautisko ekonomisko institūciju statistikas un metodologijas dokumenti.

\section{Promocijas darba ierobežojumi}

Sadarbības tīklu izmantošana ilgtermiṇā ir būtisks “born global” attīstību veicinošs faktors, tāpēc konkrētais pētījums balstās uz uzṇēmējdomāšanas individuālo raksturlielumu lomas sadarbības tīklu veidošanas procesā izpēti.

Pētījumā netiek apskatītas vispārzināmās piecas pieejas sadarbības tīklu veidošanas stratēgijām, kas ir klasificējamas kā galvenās sadarbības tīklu veidošanas iespējas, ko uzṇēmēji īsteno. Minētās stratēgiskās pieejas ir šādas: (1) personīgie kontakti; (2) stabilas attiecības ar lieliem ārvalstu klientiem un piegādātājiem; (3) atgriezeniskā saite ar klientiem; (4) progresīvu tehnoloǵiju izmantošana; (5) veidi, kā uzṇēmums ienāk starptautiskajā tirgū. Pētījumā netieši tiek aplūkotas atšķirības, kā biznesa kultūra dažādās valstīs ietekmē sadarbības tīklu attīstību, šim nolūkam uzņēmumiem būtu nepieciešamas dažāda veida stratēgijas, lai attīstītu un uzturētu kvalitatīvas ilgtermiṇa attiecības starptautiskajā tirgū. Kontekstuālie mainīgie, piemēram, ekonomiskie apstākḷi, kultūra, institucionālā vide un tirgus faktori, kas, iespējams, ietekmē to, cik ātri un kādā līmenī uzṇēmumi var ieiet globālajā tirgū, atsevišķi nav pètīti.

Šajā darbā netiek pētīta “born global” uzņēmumu preču vai pakalpojumu veida ietekme uz to īstermiņa un ilgtermiņa panākumiem.

Netiek pētīta ārèjās vides perspektīva, lai gan valsts institucionālā kvalitāte ietekmē vietējo uzṇēmējdarbības vidi, konkurenci un uzṇēmuma rentabilitāti, turpmāku orientāciju uz starptautisko tirgu. Ir zināms, ka biznesa vides nenoteiktība ir lielāka starptautiskajā mērogā tās nestabilitātes un tirgu savstarpējās mijiedarbības dēḷ, globālā biznesa vide ir saistīta ar augstu riska pakāpi. Uzṇēmējdarbības vides aspekti (piemēram, likumdošanas sistēma, nodokḷu sistēma), kas ietekmē uzṇēmējdarbību valstī, nav šì darba analīzes priekšmets. Ekonomiskā brīvība kā nozīmīgs faktors, kas nosaka ekonomisko izaugsmi kopumā, tiek aplūkota netieši.

\section{Tēzes promocijas darba aizstāvēšanai}

1. Zinātniskās literatūras analīzes rezultātā iegūto teorētisko atziṇu izklāsts, kā rezultātā tika izvirzìta pētījuma hipotēze.

2. Empīriskā pētījuma rezultātu prezentācija par uzṇēmējdomāšanas individuālo raksturlielumu īpašību klātbūtni, virzoties uz uzṇēmējdarbības aktivitātēm un rezultātiem.

3. Prezentācija ar ieteikumiem, kas izstrādāti mācību pasākumiem, lai attīstītu uzṇēmējdomāšanas individuālos raksturlielumus un uzlabotu uzṇēmēju praktiskās iemaņas, gatavojoties veiksmīgas "born global” stratēgijas izstrādei.

\section{Promocijas darba struktūra un apjoms}

Promocijas darbā ir ievads, trīs galvenās daḷas, secinājumi un ieteikumi. Darba pamatteksta apjoms ir 150 lappuses. Promocijas darba saturs ir ilustrēts ar 45 attēliem un 46 tabulām. Promocijas darbam ir pielikumi. Bibliogrāfijā ir iekl̦autas atsauces uz 284 literatūras avotiem. Darbs ietver gan teorētisku, gan empīrisku pètījumu. Autore publicējusi 14 rakstus par pètījuma tēmu un tās rezultātiem, tie publicēti 
zinātniskos žurnālos vai recenzētos zinātnisko konferenču materiālos, viens no rakstiem ir citēts zinātniskajā žurnālā. Promocijas darba rezultāti ir prezentēti 14 starptautiskās zinātniskās konferencēs, kas apstiprinātas pētniecības un studiju procesā.

\section{Promocijas darba galvenās zinātniskās novitātes}

1. Izpētīta saistība starp uzṇēmējdomāšanu, "born global” fenomenu un "born global” stratēgiju, pētot uzñēmējdomāšanas kā dinamiska procesa teorētiskos aspektus.

2. Izstrādāta jauna "born global" definīcijas kopējās izpratnes versija, to balstot kvalitatīvajos aspektos.

3. Rezultāti, kas parāda kauzācijas un izpildes teorijās balstīto uzṇēmējdomāšanas individuālo raksturlielumu nepieciešamības un pietiekamības līmeni uzņēmējiem, ir iegūti, izmantojot kvalitatīvās salīdzinošās analīzes $\left(f_{s} Q C A\right)$ metodi, kas tika pielāgota kā analīzes metode izmantošanai uzṇēmējdomāšanas pētījumu jomā pirmo reizi.

4. Rezultāti, kas iegūti, pētot topošo uzṇēmēju uzṇēmējdomāšanas individuālo raksturlielumu esamību, izmantojot $f_{S} Q C A$ metodi, ir kalpojuši par pamatu zinātniski pamatotas metodikas izstrādei, kuras mērķis ir veicināt uzṇēmējdomāšanas pilnveidi, lai virzìtu uzṇēmēju uz veiksmīgas $B G$ startēǵijas veidošanu.

\section{Promocijas darba praktiskais ieguldijums}

- Izstrādāta metodika uzṇēmējdomāšanas attīstībai un virzībai uz "born global”.

- Jaunizveidotajai metodikai ir divas dal̦as: (1) topošā uzṇēmēja gatavības kḷūt par "born global” novērtēšanas metodika; (2) metodika uzṇēmējdomāšanas pilnveidei, lai virzìtu uzṇēmēju uz veiksmīgas "born global” stratēgijas izstrādi.

\section{Izstrādātās metodikas aprobācija}

Metodika topošā uzṇēmēja gatavības pakāpes $B G$ novērtēšanai tika aprobēta LIAA Siguldas biznesa inkubatorā. Siguldas biznesa inkubatora vadība atzina, ka jaunizveidotā metodika palīdzēja viṇiem izvēlēties atbilstošākos uzṇēmumus iekḷaušanai biznesa inkubatorā.

Tika aprobēts izstrādātās metodikas, kas paredzēta uzṇēmējdomāšanas kā virzītājspēka veiksmīgas "born global” stratēgijas izveidei, tālākai attīstībai un pilnveidei, "pilotprojekts”. Apmācību rezultāti parādỉja, ka, strādājot kopā ar citiem uzṇēmējiem biznesa inkubatoros, savstarpējie kontakti var dot lielu ieguldījumu uzṇēmēju izaugsmē un virzībā uz stratēǵiskām partnerattiecībām. 


\section{PROMOCIJAS DARBA GALVENĀS NOSTĀDNES}

\section{Uzṇēmējdomāšana}

Lai izprastu uzṇēmējdomāšanas jēdziena būtību un radītu viedokli par šo koncepciju, promocijas darba autore ir izmantojusi monogrāfisko dokumentu analīzes metodi, ar kuras palīdzību veikta detalizēta pētījuma objekta izpēte, pamatojoties uz plašu zinātniskās literatūras pārskatu, kas ḷāva pētīt savstarpēji saistītus konceptus, kas lietoti dažādās zinātnes jomās.

Termins “uzṇēmējdomāšana” bieži tiek lietots kopš 2000. gada, lai aprakstītu konkrētas personas, kas darbojas biznesā, īpašîbas. Pēdējo divu desmitgažu laikā zinātnieki ir pētījuši uzṇēmējdomāšanu, meklējot atbildes uz jautājumiem, piemēram, kāpēc daži cilvēki spēj identificēt iespējas, bet citi nespēj, kā, atrodot šìs iespējas, tie spēj piesaistīt un izmantot viņu rīcībā esošus un jaunus resursus inovatīvā veidā, ņemot vērā dinamisko un sarežg̀ìto biznesa vidi.

Uzṇēmējdomāšanas definīcijas (1.1. tab.), kas atrodamas zinātniskajā un speciālajā literatūrā, ir līdzīgas cita citai. Visas tabulā apkopotās definīcijas raksturo indivīda spēju domāt, pieṇemt lēmumus, plānot un definēt mērķus, kas ir dinamiski, elastīgi un pašregulējoši dinamiskājā un ar daudziem izaicinājumiem saistītajā biznesa vidē.

1.1. tabula

\section{Uzṇēmējdomāšanas definīcijas attīstības hronoloǵiskā secība}

\begin{tabular}{|c|c|}
\hline Autors, gads & Uzṇēmējidomăšanas definīija \\
\hline $\begin{array}{l}\text { McGrath, MacMillian } \\
(2000)\end{array}$ & Spēja sajust, rīkoties un mobilizēties mainīgajā biznesa vidē \\
\hline $\begin{array}{l}\text { Ireland, Hitt, Sirmon } \\
(2001)\end{array}$ & $\begin{array}{l}\text { Uzñēmējdarbības domāšanas veids, balstoties uz kuru, mainīgā, nenoteiktā } \\
\text { biznesa vide tiek uztverta kā priekšrocība veiksmīgas uznēèejdarbības sāk- } \\
\text { šanai; uz izaugsmi, indivīda radošumu un virzību uz inovatīviem risināju- } \\
\text { miem orientēta domāšana }\end{array}$ \\
\hline Haynie, Shepherd (2007) & Spēja pielāgot domāšanu mainīgās biznesa vides noteiktajiem nosacījumiem \\
\hline $\begin{array}{l}\text { Dhliwayo, Van } \\
\text { Vuuren }(2007)\end{array}$ & Ar uzņēmējdarbību saistīts domāšanas un rīcības veids \\
\hline Haynie u. c. (2010) & $\begin{array}{l}\text { Indivīda spēja darboties dinamiski, būt elastīgam un pašregulējošam dina- } \\
\text { miskās un nenoteiktās biznesa vides nosacijjumu izzināšanas procesā }\end{array}$ \\
\hline $\begin{array}{l}\text { Shepherd, Patzelt, } \\
\text { Haynie (2010) }\end{array}$ & $\begin{array}{l}\text { Indivīda spēja un vēlme àtri sajust izmaiñas dinamiskajā biznesa vidē un } \\
\text { atbilstoši tam pieṇemt lēmumus un izstrādāt rīcíbas plānu }\end{array}$ \\
\hline Baron (2014) & $\begin{array}{l}\text { Domāt, spriest, piennemt lēmumus, plānot un definēt mērķus unikālā, tikai } \\
\text { sev raksturīgā veidā }\end{array}$ \\
\hline Davis, Hall, Mayer (2016) & $\begin{array}{l}\text { Motīvu, prasmju un domāšanas procesu konstelācija, kas atšķir uzṇēmējus } \\
\text { no tiem, kas nav uzṇēmēji }\end{array}$ \\
\hline $\begin{array}{l}\text { McMullen, Kier } \\
(2016)\end{array}$ & $\begin{array}{l}\text { Spēja apzināt un izmantot iespējas, kuras ir realizējamas, izmantojot uzṇē- } \\
\text { mēja pārziṇā esošos resursus }\end{array}$ \\
\hline Nabi u. c. (2017) & Spēja kritiski un radoši domāt \\
\hline Lindberg u. c. (2017) & Individuālo iezīmju mijiedarbības ar uzṇēmējdarbības aktivitātēm rezultāts \\
\hline Naumann (2017) & $\begin{array}{l}\text { Elastīgs domāšanas un lēmumu pieņemšanas veids, atbilstošs mainīgajai un } \\
\text { dinamiskajai biznesa videi }\end{array}$ \\
\hline
\end{tabular}


Uzñēmējdomāšanai ir vairākas kopīgas iezīmes:

- tas ir domāšanas veids, kas saitīts ar biznesu un tā iespējām mūsdienu mainīgajā biznesa vidē;

- tas atspoguḷo novatorisku un dinamisku iespēju meklēšanu un palīdz saskatīt jaunas biznesa iespējas;

- tas attiecas uz indivīdu, kurš spēj identificēt iespējas, attīstīt jaunas idejas un atklāt jaunus veidus, kā izmantot iespējas un risināt problēmas, rast radošus to risināšanas veidus;

- uzṇēmējdomāšana ir saistīta gan ar radošumu, gan inovācijām;

- uzṇēmējdomāšana ir gan individuāla, gan kolektīva vērtība, tā ir svarīga individuālajiem uzṇēmējiem, kā arī viṇu uzṇēmumu vadītājiem un darbiniekiem;

- jaunu iespēju meklēšana uzņēmējam ir svarīgs uzdevums;

- uzṇēmējdomāšana ietver indivīda uzvedības veidu, veicot uzṇēmējdarbỉbu.

Autore uzskata, ka ir svarīgi minēt pētnieku secinājumus saistībā ar uzṇēmējdomāšanas individuālajām iezīmēm (1.2. tab.):

- pastāv atšķirīibas pieejās, kā uzṇēmēji pieņem lēmumus un veido sadarbības tīklus;

- indivīda spējas pieņemt optimālus vai vismaz apmierinošus lēmumus ierobežo viṇa prāta kognitīvie faktori, kā arī informācijas un resursu esamība vai trūkums;

- kauzācijas un izpildes teorijās balstītie uzṇēmējdomāšanas individuālie raksturlielumi ietekmē uzņēmējdarbības rezultātus, jo, balstoties uz uzṇēmējdomāšanas individuālajiem raksturlielumiem, uzṇēmēji pieņem lēmumus attiecībā uz to, kā virzìties uz priekšu, sasniegt definētos mērḳus;

- uzṇēmējdomāšanas individuālie raksturlielumi ir psihologiskas konstrukcijas, kurām ir būtiska nozìme, lai izprastu uzṇēmēja uzvedību un, attiecīgi, uzṇēmējdarbības lēmumu pieṇemšanas veidu.

1.2. tabula

\section{Uzṇēmējdomāšanas individuālie raksturlielumi ${ }^{1}$}

\begin{tabular}{|c|c|}
\hline $\begin{array}{l}\text { Uznēemējdomāšanas } \\
\text { individuälais } \\
\text { raksturlielums }\end{array}$ & Uzṇēmējdomāšanas individuälā raksturlieluma skaidrojums \\
\hline Aizrautība & 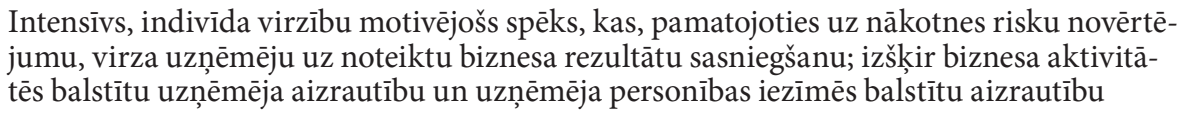 \\
\hline $\begin{array}{l}\text { Aizrautība, } \\
\text { balstīta biznesa } \\
\text { aktivitātēs }\end{array}$ & $\begin{array}{l}\text { Luauj uzṇēmējam gūt prieku no biznesa aktivitātem; uz procesu vērsta motivācija, kas } \\
\text { balstās spējā kontrolēt riskus, būt elastīgam savu mērķu sasniegšanā, atvērtam jaunai } \\
\text { pieredzei un eksperimentiem, labāk uztvert negaidìtu lēmumu pieņemšanu; spēja strā- } \\
\text { dāt kopā ar biznesa partneriem uzṇēmuma attīstības un izaugsmes posmos }\end{array}$ \\
\hline $\begin{array}{l}\text { Aizrautība, } \\
\text { balstīta uzñēmē- } \\
\text { ja personībā }\end{array}$ & 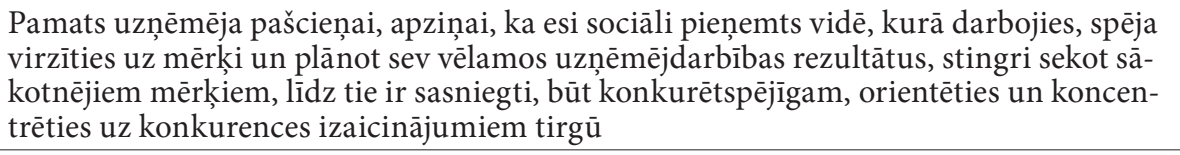 \\
\hline Pašefektivitāte & $\begin{array}{l}\text { Spēja veiksmīgi sasniegt ar uzñēmuma izveidi saistītos mērksus, pārliecības līmenis, kas } \\
\text { nepieciešams, lai uzņēmējs gūtu panākumus definēto mērḳu sasniegšanā, fokusēšanās } \\
\text { uz nākotni un veiksmes scenāriju vizualizāciju kā virzošu spēku, kāarī orientēšanās } \\
\text { uz biznesa vides piedāvātajām iespējām, skaidru, izaicinošu mērḳu noteikšanu un } \\
\text { sasniegšanu, paškontroli }\end{array}$ \\
\hline Riska uztvere & $\begin{array}{l}\text { Spēja izmantot iepriekš neprognozētu lēmumu pieņemšanas log̣iku, kur galvenā uz- } \\
\text { manība tiek vērsta uz biznesa procesa pārvaldišsanu, nevis tā rezultātiem; spēja uztvert } \\
\text { biznesa vidi kā riskantu, virzīt uzņēmumu uz priekšu nelieliem soḷiem, vienlaikus ana- } \\
\text { lizējot, kādu iespaidu tas atstāj uz kopējo biznesa mērķu sasniegšanu, un spēja meklēt } \\
\text { un atrast sadarbības partneru atbalstu, lai novērstu radušos riskus }\end{array}$ \\
\hline
\end{tabular}

Based on Bandura, 1991; Sitkin, Weingart, 1995; Chen et al., 1998; Pham, Taylor, 1999; Ryan, Deci, 2000; Hodgins, Knee, 2002 ; Vallerand et al., 2003 ; Luszczynska et al., 2005 ; Cardon et al., 2005, 2009; Vallerand et al., 2007; Sarasvathy, 2008; Sarasvathy, Dew, 2008; Read et al., 2009; Lafrenière et al., 2011; Stroe et al., 2018. 
Par 1.2. tabulā apkopoto uzṇēmējdomāšanas definīciju kopsavilkumu un mūsdienu biznesa videi atbilstošu vispārinājumu tiek uzskatīta Dr. Alaina Fayolle dinamiskā pieeja uzṇēmējdomāšanas definēšanai, kas pirmo reizi publicēta laikrakstā Financial Times 2012. gadā (Financial Times, 2012. gada 1. marts); tajā definēta uzṇēmējdomāšana kā īpašs prāta stāvoklis, kas indivīda uzvedību virza uz uzņēmējdarbības aktivitātēm un tās rezultātiem. Dr. Favole ir atzīmējis arī to, ka tieši indivīdi, kuriem piemīt uzņēmējdomāšana, biežāk saskata jaunas biznesa attīstības iespējas, ir orientēti uz inovācijām un jaunu vērtību radīšanu. Var piekrist, ka uzņēmējdomāšana ir dinamisks process, virzìts uz aktivitātēm un rezultātiem.

Šì dinamiskā pieeja (1.1. att.) tika izmantota par pamatu turpmākai uzṇēmējdomāšanas darbību un paredzamo rezultātu, kas rodas šìs dinamikas procesā, analīzei.
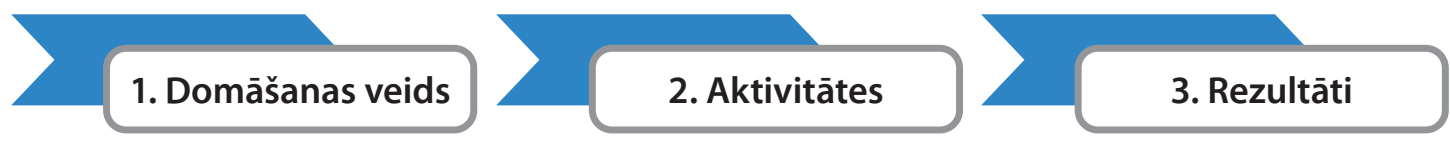

1.1. att. Uzṇēmējdomāšana kā dinamisks process (balstīts uz Dr. Alain Fayolle, 2012).

Pamatojoties uz dinamisko pieeju, turpmākā pētījuma gaitā pētīta saistība starp uzṇēmējdomāšanu un "born global" fenomenu.

\section{Saistība starp uzṇēmējdomāšanu un "born global" fenomenu}

Lai labāk izprastu šo saistību, tika nolemts sākt ar "born global” fenomena rašanās vēstures izpēti. Autore ar "born global" saistītās teorētiskās bāzes attīstības izpētes rezultātus iedalījusi trīs posmos, 2.1. attēlā parādìta secība, kādā ar katru jaunu posmu, attīstoties teorētiskajai bāzei, ir nākuši klāt arvien jauni faktori, kas raksturo "born global", teorijas ir attīstījušās līdz ar "born global" fenomena attīstību.
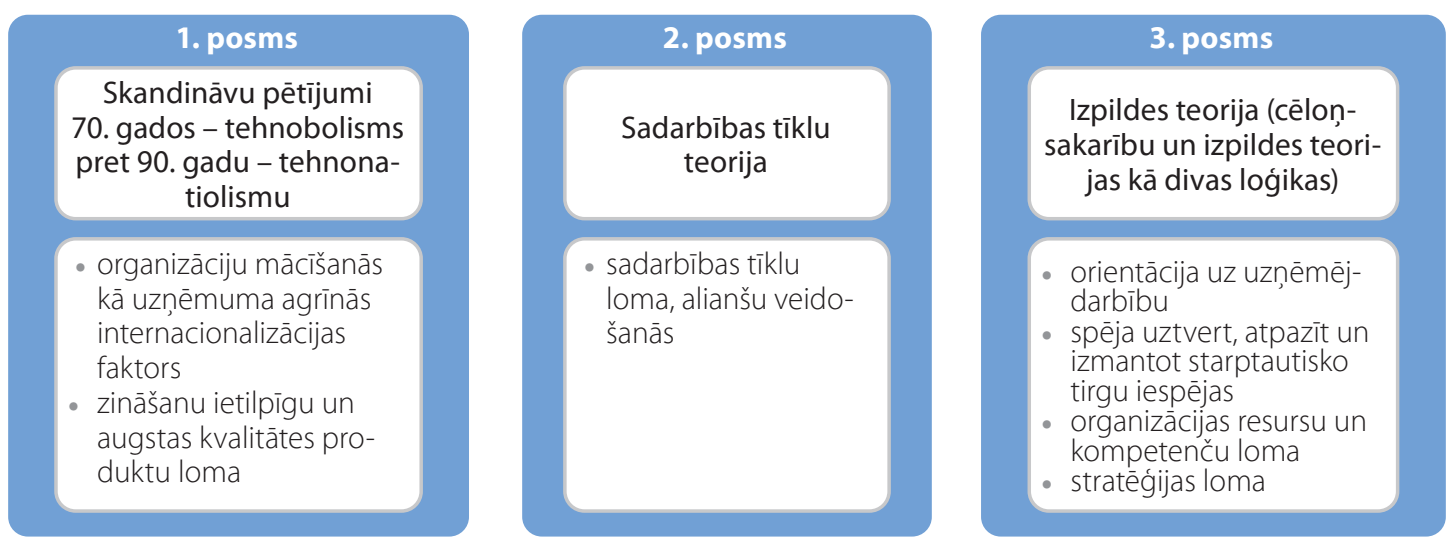

2.1. att. Galvenās "born global" teorijas un to veidošanās dažādos to pētijumu posmos.

\section{1. attēla skaidrojums}

1. posms

20. gadsimta 70. gadu skandināvu pētījumi ir sākums “born global” koncepta tālākai izpētei. 90. gadu tehnoglobālisms pret tehnoracionālismu ir sākumpunkts turpmāk paustajam viedoklim par tehnolo- 
giju lomu uzņēmumu virzībā uz globalizāciju: tiek uzsvērts, ka zināšanu ietilpīgi produkti, augstās tehnologijas, augstas kvalitātes produkti un produkti ar pievienoto vērtību veicina agrīnu uzṇēmumu internacionalizāciju; šajā laikā radās viedoklis, ka kolektīvā zināšanu apguve ir agrīno internacionalizāciju veicinošs faktors, kas pozitīvi ietekmē sniegumu starptautiskajā tirgū.

2. posms

Šo posmu galvenokārt raksturo 90. gadu sadarbības tīklu teorijas rašanās, kurā tiek uzsvērta sadarbības tīklu un alianšu loma mazo uzņēmumu internacionalizācijā, uzmanība tiek pievērsta sadarbībai, alianšu un sociālā kapitāla nozīmei "born global” internacionalizācijā un starptautiskajā sniegumā.

3. posms

Mūsdienu kauzācijas un izpildes teoriju dominances posmu raksturo koncentrēšanās uz uzṇēmējdarbības orientāciju kā potenciālu pamatu agrīnai internacionalizācijai un uz uzņēmēja iezīmēm, kas ietekmē jauno uzņēmumu internacionalizāciju jau no to pirmsākumiem. Uzṇēmuma internacionalizācijas tempu ietekmē uzṇēmēja spēja saskatìt un izmantot iespējas starptautiskajos tirgos; dinamiskas darbošanās spējas tiek minēts kā galvenais faktors, kas atbalsta agrīnu internacionalizāciju.

Iepriekš aprakstītajam ir vistiešākā saistība ar uzṇēmēja darbību, kuru virza noteikts individuālo ipašību kopums.

"Born global” uzṇēmums var izveidoties tikai ar uzṇēmēja palīdzību, kuram piemīt noteikts individuālo iezīmju kopums (2.1. tab.).

2.1. tabula

\section{“Born global" uzṇēmēja iezīmju un "born global" uzṇēmuma iezīmju apkopojums²}

\begin{tabular}{|c|c|}
\hline "Born global" uzṇēmēja iezīmes & "Born global" uzñēmuma iezimes \\
\hline $\begin{array}{l}\text { Globāls uzṇēmējs } \\
\text { Indivīds ar spēcīgu motivāciju uz } \\
\text { sasniegumiem } \\
\text { Spēcīga paškontrole, tieksme } \\
\text { uzņemties risku } \\
\text { Mazāk izvairās no riska, spēj } \\
\text { pielāgoties un vēlas mainīties } \\
\text { Proaktīva personība ar globālu } \\
\text { orientāciju } \\
\text { Definē mērḳus un cenšas tos } \\
\text { sasniegt } \\
\text { Mazāka psihologiskā distance } \\
\text { attiecībā uz ārvalstu tirgiem, jo } \\
\text { viņš/viṇa ir vairāk ceḷojis } \\
\text { Atbilstošs izglìtības līmenis, } \\
\text { pārvalda svešvalodas }\end{array}$ & 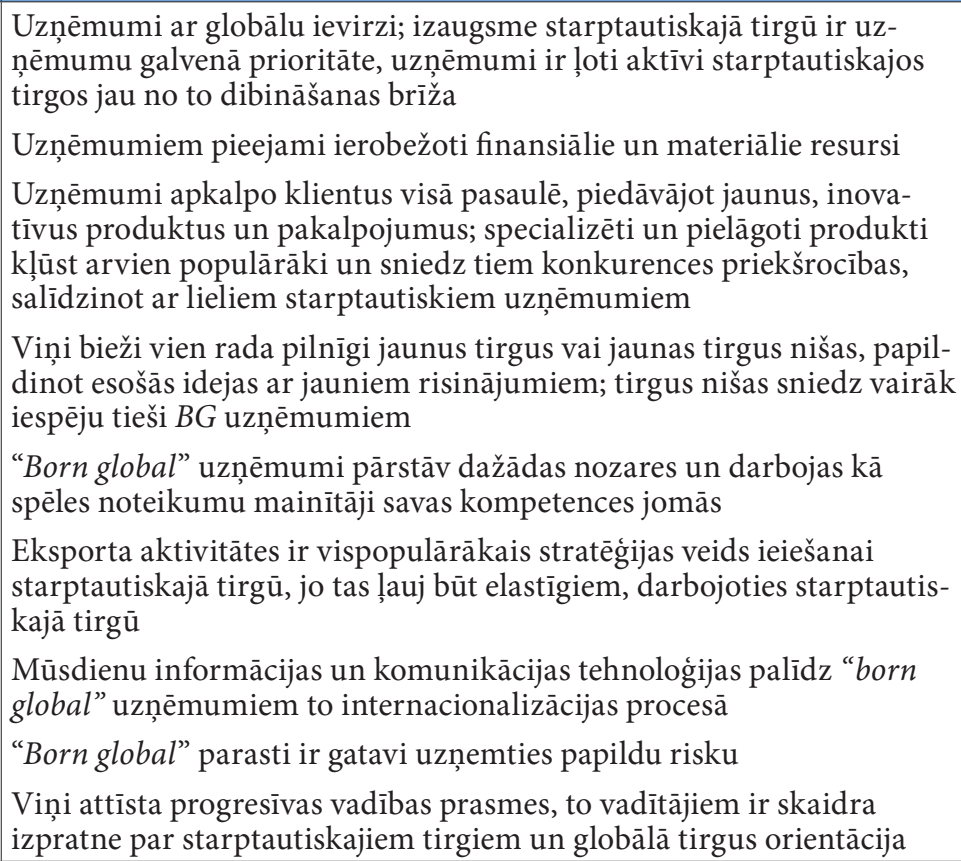 \\
\hline
\end{tabular}

Pastāv acīmredzama saikne starp uzṇēmēja iezīmēm un “born global” uzṇēmuma iezīmēm. Piemēram, uzṇēmējs ar spēcīgu iekšējās kontroles fokusu, tieksmi uz risku, aktīvu personību un globālu orientāciju ir gatavs darbībai globālajā tirgū jau no uzṇēmuma dibināšanas brīža, kā arī gatavs radīt pilnīgi jaunus tirgus, ieviest jaunas idejas, veiksmīgi izveidot jaunas tirgus nišas, izmantojot esošās

2 Balstīts uz Loane u. c., 2008; Paweta, 2013 un Rennie, 1993; Moen, 2002; Persinger u. c., 2007; Gabrielsson u. c., 2008; Paweta, 2013; Advantage Austria, 2019; Ferguson u. c., 2021. 
idejas un meklēt jaunus risinājumus.

Kauzācijas un izpildes teorijas ir izmantotas kā teorētisks pamats, lai parādītu saistību starp “born global" un uzṇēmējdomāšanas iezīmēm. Šīs teorijas apraksta aspektus, kas veido dažādas uzṇēmēju pieejas lēmumu pieṇemšanas stratēgijām.

Izpildes procesa kā stratēǵiskās lēmumu pien̦emšanas log̣ikas pamatideja ir konkrētais mērķa definēšanas un tā sasniegšanas veids, tas balstās uz:

- mērķu formulēšanu, pamatojoties uz eksperimentiem;

- pieņemamo zaudējumu principa piemērošana palīdz kontrolēt risku un pareizi izmantot ierobežotos resursus;

- fleksibilitāte palīdz darboties mainīgos biznesa vides apstākḷos un izmantot esošos resursus, tos kombinējot;

- sadarbības tīklu veidošana l̦auj uzṇēmumiem kontrolēt nākotnes plānus un novērst neskaidrības.

Kā atklājuši pētnieki, pieredzējuši uzṇēmēji savos agrīnajos internacionalizācijas centienos izmanto darbības, kas balstītas izpildes teorijas principos nevis kauzācijas pamatidejās, pamatojoties uz izpildes teorijā balstītu lēmumu pieņemšanas log̣iku, jo tā ir:

- neprognozējama log̣ika, kas vērsta uz problēmu risinājumu pārkārtošanu un esošās realitātes pārstrukturēšanu uz jaunām iespējām;

- tiek lietota dažādās uzn̦ēmējdarbības jomās, to ir pētījuši daudzi autori;

- nav pozicionēta kā "labāka" lēmumu pieṇemšanas logíka, bet gan vairāk atbilstoša mainīgajai biznesa videi;

- process prasa noteiktu līdzekḷu kopumu un koncentrēšanos uz izvēli starp iespējamiem risinājumiem, kā labāk izmantot pieejamos līdzekḷus.

Veiksmīgas "born global” stratēgijas izstrāde balstās arī uz kauzācijas un izpildes teoriju pamatprincipu kopumu, to mijiedarbỉbu.

\section{Saistība starp uzn̨ēmējdomāšanu un "born global" stratēǵiju}

Nišas stratēgija tiek uzskatīta par "born global” uzṇēmuma galveno stratēǵiju darbībai globālajā tirgū. Tirgus nišu var uzskatīt par “īpašu tirgus segmentu”, līdz ar to uzṇēmumi var izvēēēties veidot specifisku tirgus piedāvājumu, kas paredzēts konkrētam tirgus segmentam (t. i., nišas stratēgija). Tādējādi nišas nav statiskas, tās var pastāvīgi mainīties un attīstīties, balstoties uz potenciālo klientu jaunām vajadzībām, kā arī tām vajadzībām, ko pašlaik neapmierina citi tirgus piedāvājumi.

Nišas stratēgija ḷauj mazajam spēēētājam izvairīties no tiešas konkurences ar lielajiem uzṇēmumiem, kas ir orientēti uz masu tirgiem. Specializēto jomu, ko sauc par "nišām”, panākumi galvenokārt ir balstīti novitāšu ieviešanā.

Sadarbības tīkliem ir galvenā loma nišas stratēǵijas balstī̌sanā. Sadarbības tīklu veidošana ir pamats mazo uzṇēmumu veiksmīgai ieejai globālajā tirgū.

3.1. attēlā redzamas sadarbības tīklu kā nišas stratēǵijas virzītājspēka iezīmes, tie sniedz jaunas zināšanas un darbojas kā uzṇēmuma internacionalizācijas procesa neatṇemama sastāvdaḷa. 


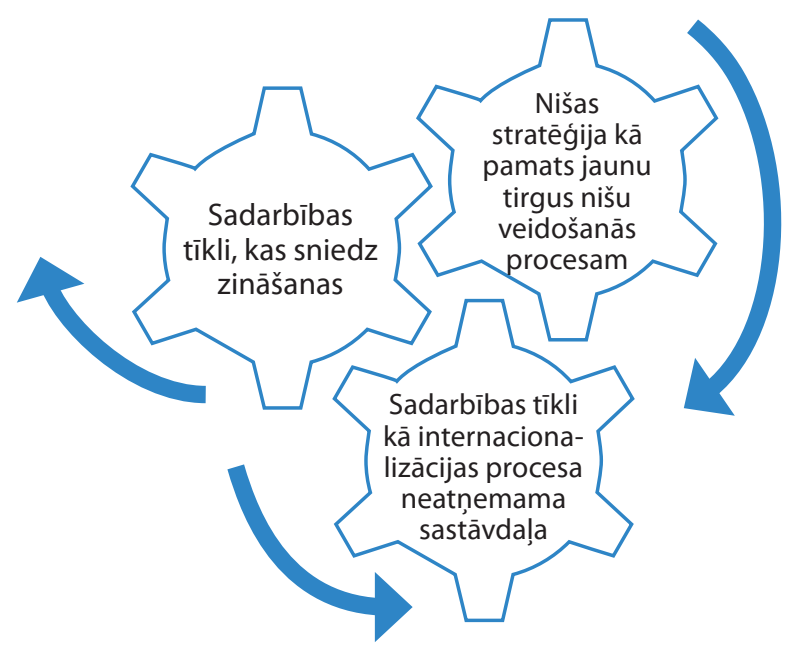

3.1. att. Sadarbības tīklu loma nišas stratēǵijas atbalstišanā (autores izstrādāts).

3.2. attēlā redzama saikne starp diviem galvenajiem sadarbības tīkla elementiem: attiecības sadarbības tìkla ietvaros kā internacionalizācijas procesa neatņemama sastāvdaḷa un savstarpējā mijiedarbība tīkla ietvaros, kas sniedz zināšanas; attēlā uzsvērtas arī galvenās iezīmes, kas raksturo katru no šiem diviem galvenajiem sadarbības tīklu elementiem.

\begin{tabular}{|c|c|}
\hline $\begin{array}{l}\text { Sadarbības tỉkli kā neatnemama uzṇēmuma } \\
\text { internacionalizācijas procesa sastāvdaḷa }\end{array}$ & $\begin{array}{l}\text { Zināšanas, } \\
\text { ko sniedz sadarbibas tikkli }\end{array}$ \\
\hline $\begin{array}{c}\text { Sadarbības tīkli palīdz BG uzñēmumiem } \\
\text { issā laikā gūt pel̦̣nu globālajā tirgū, } \\
\text { neuzṇemoties pārmērīgu risku }\end{array}$ & $\begin{array}{c}\text { Palīdz veidot jaunus un uzturēt esošos } \\
\text { kontaktus globālajā biznesa vidē, mazināt } \\
\text { mainīgās vides ietekmi uz uzñēmuma } \\
\text { izaugsmi }\end{array}$ \\
\hline $\begin{array}{l}\text { Palīdz nodrošināt piekluvi papildu } \\
\text { resursiem, kas nepieciešami pētniecībai, } \\
\text { tehnoloǵiju attīstībai, ražošanai, } \\
\text { mārketingam un produkta virzīšanai tirgū }\end{array}$ & $\begin{array}{c}\text { Sniedz uznēemumiem prasmes ātrākos } \\
\text { tempos ieiet geogrāfiski attālos tirgos, } \\
\text { kas prasa spēju uznemties lielāku saistību } \\
\text { apjomu }\end{array}$ \\
\hline
\end{tabular}

3.2. att. Saistība starp diviem galvenajiem sadarbības tīkla elementiem (autores izstrādāts).

Uzṇēmējdomāšanai ir būtiska loma sadarbības tīklu veidošanā uzṇēmējdarbības procesā, kā arī jaunu biznesa iespēju radīšanā un veicināšanā:

- uzñēmējdomāšana norāda uz domāšanas veidu, kas orientēts uz biznesa procesu un tā iespējām mainīgajos mūsdienu tirgus apstākḷıs;

- uzṇēmējdomāšana atspoguḷo novatorisku un dinamisku iespēju meklēšanu un veicina aktivitātes, kuru mērḳis ir iespēju saskatīšanaun izmantošana;

- attiecas uz indivīdu, kurš spēj identificèt iespējas, attīstīt jaunas idejas un atklāt jaunus veidus, kā atrast iespējas un risināt problēmas, tam visam pieejot radoši.

Iespēju saskatīšana uzṇēmējdarbībā pati par sevi ir resurss, jo, ja uzṇēmējam piemīt "unikāla domāšana”, tas spēs radīt konkurences priekšrocības, jo uzṇēmēja kognitīvās spējas palīdz viṇam identificēt iespējas un plānot uzṇēmuma resursus šo iespēju praktiskai realizācijai. Dažādiem uzṇēmējiem ir atšķirīgas pieejas, kā identificēt iespējas un plānot uzṇēmuma resursus. Autores pieņēmums, ka kauzācijas un izpildes teorijās ietvertie priekšstati pamatā ir balstīti uz uzṇēmējdomāšanas individuālo 
raksturlielumu līmeni uzṇēmējam kā faktoru kopumu, kas nosaka veidu, kā uzṇēmējs saskata biznesa iespējas un plāno uzņēmuma resursus. Šeit autore ir nonākusi pie pētījuma hipotēzes un pieņēmusi lēmumu to izpētīt turpmāko pētījumu gaitā.

\section{Uzṇēmējdomāšanu veidojošo faktoru analīze}

Lai pierādītu pētījuma hipotēzi, kas definēta saistībā ar uzṇēmējdomāšanas individuālajiem raksturlielumiem kā galvenajiem faktoriem, kas veido uzṇēmējdomāšanu, kā datu vākšanas rīks tika izvēlēta aptauja. Izlasē tika iekḷautas trīs respondentu grupas: jaunuzṇēmumi no Baltijas valstīm kā potenciāls agrīnai orientācija uz "born global”; gazeles - Latvijas strauji augošie uzṇēmumi. Promocijas darba autore nolēma papildus uzzināt Austrijas uzṇēmēju - uzṇēmumu īpašnieku - viedokli, kas nominēti kā “born global čempioni”. Tiešsaistes aptauja tika izvēlēta kā rīks, lai iegūtu pētījuma datus.

- Dati tika apkopoti saskañā ar Interreg Baltijas jūras regiona projekta "Smart-up akselerators" ieteikumiem, izmantota LIAA Magnetic Latvia Start-up datubāze, kā arī Lietuvas un Igaunijas Start-up uzṇēmumu datubāzes. Pētījuma periods ietvēra 2018. un 2019. gadu. Ar uzṇēmējiem no aptuveni 800 uzṇēmumiem kopumā notika sazināšanās, izmantojot e-pastu, tie tika aicināt aizpildīt tiešsaistes aptaujas anketas. Atbilžu skaits bija 20 \% no izsūtīto anketu kopskaita. Dati tika vākti, tiešsaistē aptaujājot uzṇēmumu dibinātājus, kuri bija cieši saistīti ar viņu biznesa attīstības procesu. Tika izmantoti atklātie un jaukta tipa jautājumi, lai atbildes varētu izmantot turpmākai analīzei.

- Pētījuma datu analīzes metodika ietvēra Likerta skalas izmantošanu (atbildes uz jautājumiem tika novērtētas piecos līmeņos), kas svārstījās no 1 (pilnīgi nepiekrītu) līdz 5 (pilnībā piekrītu) un kvalitatīvā salīdzinošās analīzes ( $\left.f_{s} Q C A\right)$ metode. Kvalitatīvā salīdzinošā analīze $(Q C A)$, ko 1987. gadā izstrādāja Čārlzs Ragins, ir salīdzinoša rakstura metode, kas vērsta uz vairāku faktoru mijiedarbības salīdzināšanu pētījumiem mazā vai vidējā $N$ pētījuma kopā. Nepieciešamie nosacījumi (uzņēmējdomāšanas individuālie raksturlielumi), salīdzinot tos ar kauzācijas un izpildes faktoru esamību, ir atkarīgais mainīgais, kas tika pārbaudīts pētījuma gaitā. Kauzācijas un izpildes lēmumu pieņemšanas log̣ikas faktoru esamība ir neatkarīgs mainīgais.

- Deviņos jautājumu blokos tika ietverti jautājumi par uzņēmumu kopumā un mērḳa grupā iekl̦auto respondentu attieksmi pret internacionalizācijas procesu, kā arī kauzācijas un izpildes teorijās balstītu faktoru esamību, kas saistīti ar uzṇēmējdomāšanas individuālajiem raksturlielumiem (4.1. tab.).

Pirms anketas izsūtī̌sanas respondentiem tā tika testēta ekspertu grupā, kurā bija iekḷauti deviņi dalībnieki, testēšana notika no 2019. gada 12. februāra līdz 15. februārim. Fokusa grupas diskusijā par "born global” koncepcijas izpratnes veidiem piedalījās deviṇi pieredzējuši eksperti uzṇēmējdarbības jomā, kas ir saitīti ar MVU. Fokusa grupas dalībnieku vecums bija no $26 \mathrm{līdz} 58$ gadiem, piedalījās abu dzimumu pārstāvji. Lai apstiprinātu aptaujas jautājumos iekḷautā ticamības pakāpi, kā pētijuma metode tika izvēlēta fokusa grupas diskusija. Fokusa grupas dalībniekiem tika piedāvāti seši diskusiju jautājumi par "born global” koncepciju un "born global” iezīmēm. Diskusija ilga 1,5 stundas. Ekspertu diskusijas dalībniekiem radās jautājums, kāpēc kauzācijas teorijā balstītie faktori ir izvēlēti kā mainīgie to izpētei saistībā ar uzṇēmējdomāšanas individuālajiem raksturlielumiem. Diskusijas dalïbnieki tika iepazīstināti ar kvalitatīvās salīdzinošās analīzes $\left(f_{s} Q C A\right)$ metodes būtību, kas tiks izmantota datu analīzei pēc diskusijas; ekspertu grupas lēmums par anketas lietojumu šajā aptaujā bija apstiprinošs. Pēc fokusa grupas diskusijas un pirms anketas nosūtī̌sanas respondentu izlasei tā tika pārbaudìta 20 cilvēku testa grupā laika posmā no 2019. gada 25. marta līdz 12. aprīlim. 
Aptaujas jautājumu apkopojums (autores veidota tabula)

\begin{tabular}{|c|c|c|}
\hline Jautājumu bloks & Jautäjumu bloka apraksts & Teorētiskais pamatojums \\
\hline $\begin{array}{l}\text { 1. jautājumu } \\
\text { bloks }\end{array}$ & $\begin{array}{l}\text { Vispārīgi jautājumi par uzṇē- } \\
\text { mumu }\end{array}$ & Eurostat, 2018; Paragon, 2019; OECD, 2019 \\
\hline $\begin{array}{l}\text { 2. jautājumu } \\
\text { bloks }\end{array}$ & $\begin{array}{l}\text { Uzṇēmēja starptautiskā piere- } \\
\text { dze un attieksme pret interna- } \\
\text { cionalizācijas procesu }\end{array}$ & $\begin{array}{l}\text { Erramilli, 1991; Williams, 2008; Moberg, Stenberg, } \\
\text { 2012; Nasiri, Hamelin, 2018; Asli, } 2018\end{array}$ \\
\hline $\begin{array}{l}\text { 3. jautājumu } \\
\text { bloks }\end{array}$ & $\begin{array}{l}\text { Kauzācijas teorijā balstītu } \\
\text { iezīmju izpēte }\end{array}$ & $\begin{array}{l}\text { Sarasvathy, 2001; Read, Sarasvathy, 2005; Sarasvathy, } \\
\text { Dew, 2005; Wiltbank u. c., 2006; Stroe u. c. } 2018\end{array}$ \\
\hline $\begin{array}{l}\text { 4. jautājumu } \\
\text { bloks }\end{array}$ & $\begin{array}{l}\text { Jautājumu bloks par elastīgas, } \\
\text { eksperimentos balstītas pieejas } \\
\text { nozīmi }\end{array}$ & $\begin{array}{l}\text { Jones, Coviello 2005; Schweizer u. c. 2010; Chandler } \\
\text { u. c. 2011; Galkina u. c. 2017; Stroe u. c. } 2018\end{array}$ \\
\hline $\begin{array}{l}\text { 5. jautājumu } \\
\text { bloks }\end{array}$ & $\begin{array}{l}\text { Jautājumu bloks par uzñēmēja } \\
\text { biznesa aktivitātēs balstītu } \\
\text { aizrautības līmeni }\end{array}$ & $\begin{array}{l}\text { Pham, Taylor, 1999; Ryan, Deci, 2000; Hodgins, Knee, } \\
\text { 2002; Cardon u. c., 2005; Vallerand u. c., 2010; Lafre- } \\
\text { nière u. c. 2011; Stroe u. c. } 2018\end{array}$ \\
\hline $\begin{array}{l}\text { 6. jautājumu } \\
\text { bloks }\end{array}$ & $\begin{array}{l}\text { Jautājumu bloks par uzñēmēja } \\
\text { personības iezīmēs balstītu } \\
\text { aizrautības līmeni }\end{array}$ & $\begin{array}{l}\text { Vallerand u. c., 2003; Cardon u. c., 2009; Lafrenière } \\
\text { u. c., 2011; Stroe u. c. } 2018\end{array}$ \\
\hline $\begin{array}{l}\text { 7. jautājumu } \\
\text { bloks }\end{array}$ & $\begin{array}{l}\text { Jautājumu bloks uzṇēmēja pa- } \\
\text { šefektivitātes līmeṇa izpētei }\end{array}$ & $\begin{array}{l}\text { Bandura, 1991; Boyd, Vozikis, 1994; Chen u. c., 1998; } \\
\text { Luszczynska u. c. 2005; Sarasvathy, Dew, 2008; Stroe } \\
\text { u. c. } 2018\end{array}$ \\
\hline $\begin{array}{l}\text { 8. jautājumu } \\
\text { bloks }\end{array}$ & $\begin{array}{l}\text { Jautājumu bloks uzṇēmēja riska } \\
\text { uztveres izpētei }\end{array}$ & $\begin{array}{l}\text { Ghosh, Ray, 1992; Kruege, Dickson, 1994; Sarasvathy, } \\
\text { 2008; Read u. c., 2009; Stroe u. c. } 2018\end{array}$ \\
\hline $\begin{array}{l}\text { 9. jautājumu } \\
\text { bloks }\end{array}$ & $\begin{array}{l}\text { Globālajā tirgū nepieciešamo } \\
\text { praktisko iemaṇu izpēte }\end{array}$ & $\begin{array}{l}\text { Zahra u. c., 2003; Rialp, Rialp, 2006; Zhou u. c. 2007; } \\
\text { Berends u. c., 2014; Reymen u. c., 2015; Galkina un } \\
\text { Lundgren-Henriksson, } 2017\end{array}$ \\
\hline $\begin{array}{l}\text { Noslēguma } \\
\text { jautājumi }\end{array}$ & $\begin{array}{l}\text { Būtiskākās barjeras, ieejot glo- } \\
\text { bālajā tirgū }\end{array}$ & $\begin{array}{l}\text { McKinsey, Company, 1993; Rennie, 1993; Karakaya, } \\
\text { 1993; McDougall u. c., 2003; Berends u. c., 2014; Rey- } \\
\text { men u. c., 2015; Advantage Austria, } 2018\end{array}$ \\
\hline
\end{tabular}

\section{Pētijjuma rezultātu analīze ar fsQCA metodi}

Nepieciešamo apstākḷu analīze kauzācijas un izpildes faktoru esamībai, izmantojot $f_{S} Q C A$ metodi, bija iecerēta kā pirmais analīzes solis. 4.2. un 4.3. tabulā ir iekḷauti uzṇēmējdomāšanas individuālo raksturlielumu nepieciešamības analīzes rezultāti, kuru pamatā ir kvalitatīvās salīdzinošās analīzes ( $\left.f_{s} Q C A\right)$ metode kā teorētiskās analīzes metode, kas precīzi nosaka, kā cēloṇsakarību konfigurācijas veicina konkrētu rezultātu. Pirmā analīzes kārta tika veikta, lai novērtētu, vai uzṇēmējdomāšanas individuālie raksturlielumi ir nepieciešami plānoto biznesa rezultātu sasniegšanai (nepieciešamības analīze). Kā paredz $f_{s} Q C A$ analīzes metode, faktoru nepieciešamības novērtējums tika balstīts uz konsekvences slieksni 1 . 
Kauzācijas un izpildes teorijās balstīto nosacījumu nepieciešamības analīzes rezultāti (LV) (veidojusi autore)

\begin{tabular}{|c|c|c|c|c|}
\hline \multirow{3}{*}{ Nosacijumi } & \multicolumn{4}{|c|}{ Rezultāti } \\
\hline & \multicolumn{2}{|c|}{ Kauzācijas teorija } & \multicolumn{2}{|c|}{ Izpildes teorija } \\
\hline & Blivums & Pärkläjums & Blivums & Pärkläjums \\
\hline Aizrautība, balstīta biznesa aktivitātēs & 1 & 0,476821 & 1 & 0,5 \\
\hline$\sim$ Aizrautība, balstīta biznesa aktivitātēs & 1 & 0,5 & 0,902778 & 0,656566 \\
\hline Aizrautība, balstīta uzṇēmēja personībā & 1 & 0,476821 & 1 & 0,5 \\
\hline Aizrautība, balstīta uzņēmēja personībā & 0,986111 & 0,493056 & 0,888889 & 0,646465 \\
\hline Pašefektivitāte & 0,987179 & 0,509934 & 1 & 0,541667 \\
\hline$\sim$ Pašefektivitāte & 0,987179 & 0,534722 & 0,897436 & 0,707071 \\
\hline Riska uztvere & 0,986301 & 0,476821 & 1 & 0,506944 \\
\hline$\sim$ Riska uztvere & 0,986301 & 0,5 & 0,90411 & 0,666667 \\
\hline
\end{tabular}

4.2. un 4.3. tabula ietver kauzācijas un izpildes teorijās balstīto lēmumu pieṇemšanas logikas faktoru nepieciešamības analīzes rezultātus. Apzīmējumi (LV) un (EN) nozīmē respondentu aptaujas veikšanas vienā no šīm valodām rezultātus. Šis grupēšanas veids atbilst arī $f_{s} Q C A$ koncepcijai, jo tā ir domāta kā datu analīzes metode mazām (n) pētījuma datu grupām.

4.3. tabula

Kauzācijas un izpildes teorijās balstīto nosacijjumu nepieciešamības analīzes rezultāti (EN) (veidojusi autore)

\begin{tabular}{|c|c|c|c|c|}
\hline \multirow{3}{*}{ Nosacijumi } & \multicolumn{4}{|c|}{ Rezultāti } \\
\hline & \multicolumn{2}{|c|}{ Kauzācijas teorija } & \multicolumn{2}{|c|}{ Izpildes teorija } \\
\hline & Blivums & Pārklājums & Blivums & Pārklājums \\
\hline Aizrautība, balstīta biznesa aktivitātēs & 0,982759 & 0,558824 & 1 & 0,471545 \\
\hline$\sim$ Aizrautība, balstīta biznesa aktivitātēs & 1 & 0,527273 & 0,982759 & 0,606383 \\
\hline Aizrautība, balstīta uzṇēmēja personībā & 0,981132 & 0,509804 & 1 & 0,430894 \\
\hline Aizrautība, balstīta uzņēmēja personībā & 1 & 0,481818 & 1 & 0,56383 \\
\hline Pašefektivitāte & 0,983051 & 0,568627 & 1 & 0,479675 \\
\hline$\sim$ Pašefektivitāte & 1 & 0,536364 & 0,966102 & 0,606383 \\
\hline Riska uztvere & 0,982143 & 0,539216 & 1 & 0,455285 \\
\hline$\sim$ Riska uztvere & 1 & 0,509091 & 1 & 0,595745 \\
\hline
\end{tabular}

Faktoru esamības pietiekamība nozīmē, ka plānoto rezultātu var sagaidìt vienmēr, kad šis nosacījums izpildīsies, t. i., kad uzṇēmējdomāšanas individuālo raksturlielumu līmenis būs pietiekams. 
4.4. tabula

Kauzācijas un izpildes teorijās balstīto nosacijumu pietiekamības analīzes rezultāti (LV) (veidojusi autore)

\begin{tabular}{|c|c|c|c|c|}
\hline \multirow{3}{*}{ Nosacijumi } & \multicolumn{4}{|c|}{ Rezultāti } \\
\hline & \multicolumn{2}{|c|}{ Kauzācijas teorija } & \multicolumn{2}{|c|}{ Izpildes teorija } \\
\hline & $I A$ & IIA & IB & $\| B$ \\
\hline Aizrautība, balstīta biznesa aktivitātēs & $\bullet$ & $\bullet$ & $\bullet$ & $\bullet$ \\
\hline Blivums & 1 & 1 & 1 & 0,9 \\
\hline Sākotnējais pārklājums & 0,48 & 0,5 & 0,5 & 0,66 \\
\hline Kopējais pārklājums & 0,48 & 0,5 & 0,5 & 0,66 \\
\hline Rezultējošais blīvuma aprēķins & 1 & 1 & 1 & 0,9 \\
\hline Rezultējošais pārklājuma aprēķins & 0,48 & 0,5 & 0,5 & 0,66 \\
\hline Aizrautība, balstīta uzņēmēja personībā & $\bullet$ & $\bullet$ & $\bullet$ & $\bullet$ \\
\hline Blīvums & 1 & 0,99 & 1 & 0,89 \\
\hline Sākotnējais pārklājums & 0,48 & 0,49 & 0,5 & 0,65 \\
\hline Kopējais pārklājums & 0,48 & 0,49 & 0,5 & 0,65 \\
\hline Rezultējošais blīvuma aprēķins & 1 & 0,99 & 1 & 0,89 \\
\hline Rezultējošais pārklājuma aprēḳins & 0,48 & 0,5 & 0,5 & 0,65 \\
\hline Pašefektivitāte & $\bullet$ & $\bullet$ & $\bullet$ & $\bullet$ \\
\hline Blivums & 0,99 & 0,99 & 1 & 0,9 \\
\hline Sākotnējais pārklājums & 0,51 & 0,53 & 0,54 & 0,71 \\
\hline Kopējais pārklājums & 0,51 & 0,53 & 0,54 & 0,71 \\
\hline Rezultējošais blīvuma aprēķins & 0,99 & 0,99 & 1 & 0,9 \\
\hline Rezultējošais pārklājuma aprēķins & 0,51 & 0,53 & 0,54 & 0,71 \\
\hline Riska uztvere & $\bullet$ & $\bullet$ & $\bullet$ & $\bullet$ \\
\hline Blīvums & 0,99 & 0,99 & 1 & 0,9 \\
\hline Sākotnējais pārklājums & 0,48 & 0,5 & 0,51 & 0,67 \\
\hline Kopējais pārklājums & 0,48 & 0,5 & 0,51 & 0,67 \\
\hline Rezultējošais blīvuma aprēķins & 0,99 & 0,99 & 1 & 0,9 \\
\hline Rezultējošais pārklājuma aprēksins & 0,48 & 0,5 & 0,51 & 0,67 \\
\hline
\end{tabular}

4.4. un 4.5. tabulā ir parādīti kauzācijas un izpildes teorijās balstīto uzṇēmējdomāšanas individuālo raksturlielumu pietiekamības rādītāji. Apzīmējumi (LV) un (EN) nozīmē respondentu atbilžu izmantošanu, kuri pieder vienai no šìm konkrētajām grupām. Šis grupēšanas veids ir saglabāts $f_{s} Q C A$ analīzes koncepcijas dēḷ, jo tā paredzēta mazām (n) pētījumu grupām. Pētījuma rezultāti, kas atspoguḷoti 4.4. un 4.5. tabulā, liecina par pietiekamu individuālo raksturlielumu līmeni, lai uzṇēmēji varētu pamatot savus lēmumus kauzācijas un izpildes lēmumu pieņemšanas logiikā. Viduvēji pietiekamības rādītāju rezultāti visos gadijjumos atspoguḷo nepieciešamību labāk empīriski izskaidrot aptaujāto respondentu grupai kauzācijas un izpildes teorijās balstītu lēmumu pieņemšanas log̣ikas būtību. 
Kauzācijas un izpildes teorijās balstīto nosacijumu pietiekamības analīzes rezultāti (EN) (veidojusi autore)

\begin{tabular}{|c|c|c|c|c|}
\hline \multirow{3}{*}{ Nosacijumi } & \multicolumn{4}{|c|}{ Rezultāti } \\
\hline & \multicolumn{2}{|c|}{ Kauzäcijas teorija } & \multicolumn{2}{|c|}{ Izpildes teorija } \\
\hline & IA & IIA & $I B$ & $\| B$ \\
\hline Aizrautība, balstīta biznesa aktivitātēs & $\bullet / 0$ & $\bullet / 0$ & $\bullet$ & $\bullet$ \\
\hline Blīvums & 0,98 & 1 & 1 & 0,98 \\
\hline Sākotnējais pārklājums & 0,56 & 0,53 & 0,47 & 0,61 \\
\hline Kopējais pārklājums & 0,56 & 0,53 & 0,47 & 0,61 \\
\hline Rezultējošais blīvuma aprēķins & 0,56 & 0,53 & 0,47 & 0,61 \\
\hline Rezultējošais pārklājuma aprēķins & 0,98 & 1 & 1 & 0,98 \\
\hline Aizrautība, balstīta uzṇēmēja personībā & $\bullet$ & $\bullet$ & $\bullet$ & $\bullet$ \\
\hline Blīvums & 0,98 & 1 & 1 & 0,98 \\
\hline Sākotnējais pārklājums & 0,51 & 0,48 & 0,43 & 0,57 \\
\hline Kopējais pārklājums & 0,51 & 0,48 & 0,43 & 0,57 \\
\hline Rezultējošais blīvuma aprēķins & 0,98 & 1 & 1 & 0,98 \\
\hline Rezultējošais pārklājuma aprēķins & 0,51 & 0,48 & 0,43 & 0,57 \\
\hline Pašefektivitāte & $\bullet$ & $\bullet$ & $\bullet$ & $\bullet$ \\
\hline Blīvums & 0,98 & 1 & 1 & 0,97 \\
\hline Sākotnējais pārklājums & 0,57 & 0,54 & 0,48 & 0,61 \\
\hline Kopējais pārklājums & 0,57 & 0,54 & 0,48 & 0,61 \\
\hline Rezultējošais blīvuma aprēķins & 0,57 & 1 & 1 & 0,97 \\
\hline Rezultējošais pārklājuma aprēḳins & 0,57 & 0,54 & 0,48 & 0,61 \\
\hline Riska uztvere & $\bullet$ & $\bullet$ & $\bullet$ & $\bullet$ \\
\hline Blīvums & 0,98 & 1 & 1 & 1 \\
\hline Sākotnējais pārklājums & 0,54 & 0,51 & 0,46 & 0,6 \\
\hline Kopējais pārklājums & 0,54 & 0,51 & 0,46 & 0,6 \\
\hline Rezultējošais blīvuma aprēķins & 0,98 & 1 & 1 & 1 \\
\hline Rezultējošais pārklājuma aprēḳins & 0,54 & 0,51 & 0,46 & 0,6 \\
\hline
\end{tabular}

4.4. un 4.5. tabulā melnie ap̣̣i (•) norāda par nosacījuma esamību, baltie apḷi (০) - par nosacījuma neesamību.

Pētījuma rezultāti, kas iegūti ar $f_{s} Q C A$ metodi, norāda par kauzācijas nosacījumu esamību, kas balstīti uz tās saistību ar uzṇēmējdarbības pašefektivitāti kā uzṇēmējdomāšanas vienu no individuālajiem raksturlielumiem. Uzṇēmēja aizrautības līmenis arī ir balstīts kauzācijas lēmumu pieņemšanas loğikā, saistot to ar uzṇēmēja attieksmi pret riskiem mainīgajā tirgus situācijā. Izpildes teorijā balstīto nosacījumu klātbūtnei svarīga loma ir divu uzņēmējdomāšanas individuālo raksturlielumu - aizrautỉbas un pašefektivitātes - apvienojumam; riska uztveres mainīgajā biznesa vidē kombinācijā ar uzṇēmēja aizrautîbu ir nepieciešama, lai pamatotu izpildes teorijā balstīta, neprognozējama lēmumu pieņemšanas procesa izvēli. Ar šo tiek apstiprināta pētījuma hipotēze.

Pētījuma rezultāti, kas atspoguḷoti 4.4. un 4.5. tabulā, liecina par pietiekamu iezìmju līmeni, lai uzṇēmēji izmantotu kauzācijas un izpildes teorijās balstītu lēmumu pieṇemšanas loǵiku, tajā pašā laikā viduvēji nosacījumu pietiekamības rādītāju rezultāti visos gadỉjumos atspoguḷo nepieciešamību veikt dziḷāku empīrisku izskaidrojumu uzṇēmējiem par kauzācijas un izpildes teorijās balstītu lēmumu pieņemšanas loǵiku un to nepieciešamību, virzoties uz mērķi, šajā gadījumā, virzīties uz veiksmīgas "born global” stratēgijas izstrādi. Tika nolemts šim mērḳim izstrādāt pētījuma rezultātos balstītu apmācību 
metodiku biznesa inkubatoriem, to balstot aktivitātēs, kas vērstas uz uzṇēmējdomāšanas kā individuālo raksturlielumu kopumu attīstību, ar mērḳi virzīties uz veiksmīgas "born global” stratēgeijas izstrādi.

\section{Metodika uzñēmējdomāšanas virzīšanai uz "born global"}

Promocijas darba mērḳis ir izstrādāt un apstiprināt metodiku, lai ar tajā iekḷautajām mācību programmām veicinātu uzṇēmējdomāšanas kā virzịtājspēka veiksmīgas "born global” stratēgijas izveidei attīstību, tāpēc ir izveidota metodika uzṇēmējdomāšanas virzības uz "born global” veicināšanai. Tai ir divas daḷas: (1) topošā uzṇēmēja gatavības pakāpes kḷūt par "born global” novērtēšanas metodika; (2) metodika uzṇēmējdomāšanas attīstǐšanai un virzišanai uz veiksmīgas "born global” stratēgijas izveidi kā plānoto rezultātu.

Izmantojot mācību programmas uzṇēmējdomāšanas attīstībai, lai virzìtos uz veiksmīgas “born global" stratēgiijas izveidi, ir paredzēts, ka topošie uzn̦ēmēji tiks atbalstīti, lai veicinātu viṇu individuālās pieejas attīstību veiksmīgas "born global” stratēgijas īstenošanai. Apmācību metodikas mērķis ir sniegt topošajiem vai jau esošajiem uzṇēmējiem skaidrību par turpmāko biznesa izaugsmes procesa gaitu, rodot atbildi uz jautājumu, kā to sasniegt.

Tika aprobēts apmācību metodikas "pilotprojekts". Mācību rezultātu novērtēšana tika nodrošināta LIAA Siguldas biznesa inkubatorā. Novērtējuma mērḳis bija noskaidrot apmācības procesa sākotnējos rezultātus, vajadzības gadījumā metodiku pilnveidot, jo kopējais apmācību procesa mērḳis ir balstīties apmācību rezultātos, lai turpinātu izstrādāt cel̦vedi veiksmīgai, konkurētspējīgai stratēgijai globālajā tirgū. Tika veikta dalībnieku anketēšana par viņu ieguvumiem no apmācības procesa, ņemti vērā viṇu sasniegtie rezultāti un ieteikumi tālākai apmācību procesa pilnveidei.

Pētījuma mērḳis - izstrādāt un apstiprināt pētījuma rezultātos balstītu apmācību metodiku biznesa inkubatoriem, lai sniegtu uzṇēmējiem zināšanas un pārliecību, kas virzītu viṇus uz uzṇēmējdomāšanas attīstību kā individuālo raksturlielumu kopumu, rezultējoties veiksmīgas "born global" stratēgijas izstrādē, - ir sasniegts. 


\section{PROMOCIJAS DARBA GALVENIE SECINĀJUMI UN PRIEKŠLIKUMI}

Promocijas darbā veiktā pētījuma rezultātā autore ir nonākusi pie vairākiem secinājumiem.

1. Mazie un vidējie uzñēmumi (MVU) tiek uzskatīti par ekonomiskās izaugsmes dzinējiem, tiem ir galvenā loma nodarbinātības iespēju radīšanā, produktu ar pievienoto vērtību ražošanā un inovāciju kā valstu ekonomikās attīstības virzìtājspēka veicināšanā. Šie ir galvenie faktori, kas veido mūsdienu uzñēmējsabiedrības fenomenu.

2. Mazie un vidējie uzṇēmumi arvien vairāk ienāk starptautiskajos tirgos, lai piedāvātu savu inovatīvo produktu un pakalpojumu potenciālu plašākam klientu lokam, censtos pielāgoties, konkurētu, augtu un izdzīvotu starptautiskajos tirgos. Uzṇēmumu dibinātāju orientācija uz globālajiem tirgiem arvien pieaug, un tā rezultātā ir radies fenomens - "born global” uzṇèmumi, kas apstrīd tradicionālās pieejas internacionalizācijas procesam.

3. Vietējo ekspertu fokusa grupas diskusiju rezultātā tika atrasta vienota izpratne par "born global" definīciju: "Born global” ir uzṇēmums, kas orientēts uz ieņēmumu gūšanu no starptautiskā tirgus un ir spējīgs piedāvāt produktus, kas atbilst starptautiskā tirgus klientu vajadzībām; tas ir uzņēmums, kas izmanto modernās tehnologijas.

4. "Born global” uzṇēmums var izveidoties tikai ar uzn̦ēmēja palīdzību, kuram piemìt noteikts individuālo iezīmju kopums.

5. Uzñēmējdomāšana ir īpašs prāta stāvoklis un dinamisks process, kas orientē indivīda domāšanu uz ar uzṇēmējdarbības procesu saistītām aktivitātēm un to rezultātiem.

6. Uzṇēmējdomāšanas individuālie raksturlielumi ir galvenie faktori, kas veido īpašu prāta stāvokli, kas orientē indivīdu uz uzṇēmèjdarbības procesu un tā rezultātiem.

7. Zinātniskās literatūras analīze atklāj, ka dažādos internacionalizācijas periodos valdošās teorijas ir virzījušas biznesa attīstības gaitu uz "born global" uzṇēmumu parādīšanos. "Born global” lēmumu pieṇemšanas startēgijas sakṇojas kauzācijas un izpildes teorijās. Abas minētās log̣ikas ir ciešā mijiedarbībā, ir konceptualizētas kā divas galvenās "born global” lēmumu pieṇemšanas stratēgijas, vienlaikus kalpojot par galveno teorētisko pamatu "born global” fenomena izplatības periodā.

8. Nišas stratēgija ḷauj mazajiem spēlētājiem globālajā tirgū, kā "born global”, izvairīties no tiešas konkurences ar lielākiem, plaši pazīstamiem uzṇēmumiem, kuriem ir tendence orientēties uz masu tirgiem. Specializēto jomu, ko sauc par "nišām”, panākumi pirmām kārtām ir balstīti inovāciju ieviešanā. Sadarbības tīklu veidošanai ir galvenā nozīme nišas stratēgiju veidošanā un atbalstǐšanā.

9. "Born global" gadījumā uzṇēmējdomāšanas individuālie raksturlielumi ir pamatā ìpašam prāta stāvoklim, kas orientē uzṇēmēju uz konkrētiem rezultātiem, piemēram, uz veiksmīgi izveidotu nišas stratēgiju, kuras virzịtājspēks ir uzṇēmēja iekḷaušanās sadarbības tīklos. Šeit arī redzamas saikne starp uzñēmējdomāšanu, "born global” fenomenu un "born global” stratēgiju.

10. Kā pētījuma datu vākšanas rīks tika izvēlēta aptaujas metode, kas ir uzskatāma par kvalitatīvu datu apkopošanas metodi un l̦auj ņemt vērā respondentu dažādos uzskatus un pieredzi.

11. Aptaujas datu analīzei tika izmantota kvalitatīvā salīdzinošā analīze ( $\left.f_{s} Q C A\right)$. Fs $Q C A$ metodes lietošana bija veiksmīga, lai gan šo sarežǧìto matemātisko metodi uzṇēmējdomāšanas pētījumu jomā izmanto l̦oti reti.

12. Pētijuma rezultāti rāda, ka ir nepieciešams dziḷāk skaidrot aptaujātajai respondentu grupai kauzācijas un izpides teorijās balstītu lēmumu pieṇemšanas log̣iku, jo "born global” uzṇēmumi parasti darbojas jaunās tirgus nišās un tām jāpien,em lēmumi, saistīti ar riska klātesamību.

13. Tika secināts, ka ir nepieciešamas apmācību programmas, lai uzlabotu izpratni par kauzācijas un izpildes teorijās pamatotu lēmumu pien̦emšanas logiku, un šìm programmām vajadzētu būt balstītām uz uzṇēmējdomāšanas individuālo raksturlielumu līmeṇa uzlabošanu. Veiksmīga “born 
global"stratēgiija ir uzṇēmējdomāšanas kā dinamiska procesa rezultāts, kas sakṇojas uzṇēmējdomāšanas individuālajos raksturlielumos.

14. Jāveido metodika uzṇēmējdomāšanas virzībai uz "born global”. Metodikā jāieietver divas daḷas: (1) topošā uzṇēmēja gatavības būt "born global” novērtējuma metodikai; (2) metodikai uzṇēmējdomāšanas veicināšanai, lai virzìtos uz veiksmīgas "born global” stratēgijas izveidi.

15. Metodikas aprobācijai tika izvēlēti LIAA biznesa inkubatori kā organizācijas, kuru mērḳis ir paàtrināt uzṇēmumu izaugsmi un panākumus, izmantojot virkni uzṇēmējdarbības atbalsta resursu un pakalpojumu.

16. Mācību programmas ir sekmīgi izveidotas un ieviestas, to uzdevums - pilnveidot uzṇēmēju gatavības pakāpi ienākt starptautiskajā tirgū - ir izpildìts.

17. Rezultāti, kas iegūti, novērtējot mācību procesa efektivitāti, kas tika iegūti pēc dalíbnieku prezentācijas pirmā mācību posma nobeigumā, ir izmantojami, lai turpinātu metodikas tālāku pilnveidi.

18. Pētījuma mērķis - izpētīt uzṇēmējdomāšanas kā dinamiska procesa teorētiskos aspektus un tā mijiedarbību ar "born global” fenomenu, kā arī izstrādāt un apstiprināt metodiku uzṇēmējdomāšanas attīstībai kā virzītājspēkam veiksmīgas "born global” stratēgijas izstrādei - ir sasniegts.

\section{Priekšlikumi}

\section{Politikas veidotājiem}

1. "Born global" uzņēmumi Latvijas ekonomikai vēl ir jauna un mazpazīstama joma, tāpēc autores lēmums ir izmantot pētījuma rezultātus, lai stimulētu politikas veidotāju interesi veicināt un paàtrināt mazo un vidējo uzṇēmumu eksporta aktivitātes, kas ir pamats ekonomikas izaugsmei un varētu veicināt jaunu darba vietu radīšanu Latvijā.

2. Lai panāktu ekonomikas izaugsmi, radìt interesi MVU kā potenciālajiem "born global” par starptautiskajiem tirgiem, īstenojot dažāda veida valdības atbalsta iniciatīvas.

3. Ieteicamās valdības atbalsta MVU formas varētu būt ar finansiālu palīdzību saistītas atbalsta iniciatīvas un mārketinga atbalsta iniciatīvas (saistītas ar informāciju sniegšanu, apmācību organizēšanu). Ar valsts aǵentūru starpniecību potenciālajiem eksportētājiem vajadzētu veicināt piekḷuvi zināšanām par ārvalstu tirgiem, sniedzot arī zināšanas par starptautiskajiem tirgiem.

\section{Pētniekiem un akadēmiskajam personālam}

4. Jāveic turpmāki pētījumi par jautājumiem, kas saistīti ar "born global” stratēǵiju integrēšanu mūsdienu uzṇēmuma stratēgiskās attīstības modelī, lai veicinātu uzṇēmumu izpratni par to, cik svarīgi ir darboties pasaules tirgū.

5. Jāveic turpmāki pētījumi, kas pārbaudītu šajā pētījumā piedāvātās metodikas funkcionalitāti, jāveicina turpmāka diskusija starp pētniekiem un praktiķiem, samazinot plaisu starp teoriju un praksi, pētot attiecības starp "born global” fenomenu, uzṇēmēju kā galveno šo procesu faktoru un uzñēmējdomāšanu.

6. Nebaidīties iesaistīt MVU kā potenciālu “born global” kopīgos pētniecības un attīstības projektos, neņemot vērā to, ka mazie uzṇēmumi ir vairāk pakḷauti riskiem, kas saistīti ar pētniecību un attīstību. Ieguvumi no šiem sadarbỉbas projektiem ir: tie samazina riskus un izmaksas un l̦auj mazajiem uzṇēmumiem piekḷūt jaunai informācijai.

\section{Biznesa uzṇēmumiem un biznesa inkubatoriem}

7. Jaunie uzñēmumi ir jaunpienācēji starptautiskajos tirgos, tie ražo un piedāvā inovatīvus produktus globālā mērogā, tāpēc ir jāstimulē zināšanu iegūšana un jāpiedāvā valdības atbalsta iniciatīvas, līdz ar to jāveicina uzṇēmumu sniegums starptautiskajā tirgū.

8. Jāveicina uzṇēmēju savstarpējo kontaktu veidošanās, ņemot vērā to nozīmi zināšanu un resursu plūsmās un to pieejamībā.

9. Promocijas darbā veiktā pētījuma empīriskos rezultātus var izmantot, lai padziḷinātu interesi par apmācību un individuālo biznesa treniṇu programmām, kas veicinātu topošo uzṇēmēju personisko iezīmju attīstību, lai stimulētu viṇu pārliecību meklēt iespējas darboties starptautiskajos tirgos. 


\section{AUTORES PUBLIKĀCIJAS PAR PROMOCIJAS DARBA TĒMU}

Promocijas darba rezultāti ir atspoguḷoti 14 zinātniskās publikācijās.

\section{Zinātniskie raksti, kas indeksēti Web of Science un/vai Scopus zinātniskajās datubāzēs}

1. Vaivode, I. (2018). Born Global Companies. Is this a Future for Economy of Latvia? A Preliminary Study. Business: Theory and Practice, Vol. 19, pp. 288-299. ISSN 1648-0627. e-ISSN 1822-4202. Pieejams: doi:10.3846/btp.2018.29.

2. Vaivode, I. (2015). Triple Helix Model of University-Industry-Government Cooperation in the Context of Uncertainties. Procedia - Social and Behavioral Sciences, Vol. 213, pp. 1063-1067. ISSN 1877-0428. Pieejams: doi:10.1016/j.sbspro.2015.11.526.

\section{Anonīmi recenzēti zinātniski raksti, kas publicēti starptautiskos žurnālos un pieejami citās zinātniskajās datubāzēs}

3. Vaivode, I., Ščeulovs, D. (2019). The Relevance of "Born Global” Definition in the Research Process. Trends Economics and Management, Vol. 34, Iss. 2, pp. 113-124. ISSN 1802-8527. e-ISSN 2336-6508. Pieejams: doi:10.13164/trends.2019.34.113.

4. Vaivode, I., Jurēnoks, V. (2014). The Role of Innovations in Sustainable Development of State Economy. Управление и устойчиво развитие = Management and Sustainable Development, Vol. 45, No. 2, 27.-34. lpp. ISSN 1311-4506.

5. Jansons, V., Jurēnoks, V., Didenko, K., Vaivode, I. (2013). Assesment of Dynamics of the Index of the Innovation (SII) and Its Influence on Gross Domestic Product of Latvia. Management and Sustainable Development, Vol. 39, pp. 4-10. ISSN 1311-4506.

\section{Publikācijas konferenču materiālos, kas indeksēti Web of Science un/vai Scopus}

6. Vaivode, I., Ščeulovs, D. (2020). Identification and Creation of Business Opportunities as the Characteristic of the Entrepreneurial Mindset. The 24th World Multi-Conference on Systemics, Cybernetics and Informatics (WMSCI 2020): Proceedings. Vol. 3. ISBN: 978-1-950492-45-9.

7. Vaivode, I., Gaile-Sarkane E. (2016). Evolution of "Design" Concept and Its Application to Innovation in Latvia. Smart and Efficient Economy: Preparation for the Future Innovative Economy: 21st International Scientific Conference Economics and Management (ICEM 2016): Proceedings of Selected Papers, Czech Republic, Brno: Brno University of Technology, Faculty of Business and Management, pp. 246-254.

8. Vaivode, I., Jurēnoks, V. (2014). Innovation Policy in the Context of Nowadays Globalisation. Business and Management 2014: 8th International Scientific Conference: Selected Papers, Lithuania, Vilnius, pp. 460-468. ISBN 978-609-457-650-8. e-ISBN 978-609-457-649-2. ISSN 2029-4441. e-ISSN 2029-929X.

\section{Citas publikācijas konferenču (ieskaitot vietējo) materiālos}

9. Vaivode, I., Straujuma, A., Gaile-Sarkane, E. (2016). What Latvia Can Learn from Israel UniversityIndustry Innovation Cooperation. Challenges and Solutions for Fostering Entrepreneurial Universities and Collaborative Innovation: University-Industry Interaction Conference, Netherlands, Amsterdam, pp. 13-28. ISBN 978-94-91901-21-8.

\section{Publikācija zinātniskā konferences mājaslapā}

10. Vaivode, I. (2015). Innovation Policy, Globalisation in Terms of Uncertainty [online]. 2015. Available from: http://2015.euramfullpaper.org/program/papers.asp. 


\section{Publikācijas konferenču tēžu krājumos}

11. Vaivode, I. (2015). The Interaction of Exploitative, Explorative, Open, Closed Innovations and Different Innovation Strategies. 56th International Riga Technical University Conference "Scientific Conference on Economics and Entrepreneurship": Proceedings, Latvia, Riga. ISBN 978-9934-8275-3-2. ISSN 2256-0866.

12. Vaivode, I. (2014). Benchmarking Analysis of Four Performance Groups Identified by EU Innovation Union Scoreboard. 55th International Riga Technical University Conference "Scientific Conference on Economics and Entrepreneurship” Proceedings, Latvia, Riga, Technical University, pp. 1-2. ISBN 978-9934-8275-2-5.

13. Vaivode, I., Jurēnoks, V. (2014). The Assessment of Science, Technology and Innovation Policy of Latvia. Proceedings of 12th Annual BMDA Conference "Successful 21st Century Organization", Latvia, Riga. ISBN 978-9934-10-559-3.

14. Vaivode, I., Jurēnoks, V. (2013). Using of Technology Audit and Modelling Methods for Innovation System Development in Latvia. 54th International Riga Technical University Conference "Scientific Conference on Economics and Entrepreneurship” [CD-ROM] : SCEE '2013 : Proceedings, Latvia, Riga, Riga Technical University, pp. 1-1. ISBN 979-9934-10-294-3.

\section{Pētījuma rezultātu prezentācija un aprobācija starptautiskās zinātniskās konferencēs ārzemēs}

15. The 24th World Multi-Conference on Systemics, Cybernetics and Informatics (WMSCI 2020), 13-16 September 2020, Virtual Conference, US.

16. 17th International Scientific Conference "Perspectives of Business and Entrepreneurship Development in Digital Transformation of Corporate Business", 30 April 2019, Brno University of Technology, Faculty of Business and Management, Czech Republic.

17. 10th International Scientific Conference "Business and Management" 2018, 3-4 May 2018, Vilnius Gediminas Technical University, Lithuania.

18. University-Industry Interaction Conference, Netherlands, Amsterdam, 1-3 June 2016.

19. 21st International Scientific Conference "Smart and Efficient Economy: Preparation for the Future Innovative Economy", 19-20 May 2016, Brno University of Technology, Faculty of Business and Management, Czech Republic.

20. International Scientific Conference "Economics and Management - 2015" hosted by School of Economics and Business Kaunas University of Technology, held in Kaunas, Lithuania, 6-8 May 2015.

21. 8th Interntional Scientific Conference "Business and Management'2014", 15-16 May 2014, Vilnius Gediminas Technical University, Lithuania.

22. 16th International Scientific Conference on Management and Sustainable Development, Yundola 2014, Bulgaria.

\section{Pētijjumu rezultātu prezentācija un aprobācija starptautiskās zinātniskās konferencēs Latvijā}

23. 22nd International Scientific Conference Economics and Management, ICEM, 2017, 10-12 May 2017, Riga.

24. RTU 55th International Scientific Conference "Scientific Conference on Economics and Entrepreneurship (SCEE'2015)”, 15 October 2015.

25. RTU 55th International Scientific Conference "Scientific Conference on Economics and Entrepreneurship (SCEE'2014)”, 15 October 2014.

26. 12th Annual BMDA Conference "A Successful 21st Century Organization", 7-9 May 2014, Riga, Latvia.

27. RTU 54th International Scientific Conference "Scientific Conference on Economics and Entrepreneurship (SCEE’2013)”, 15 October 2013.

\section{Dalïba pētniecības projektos}

28. Participation in the EIT Climate-KIC Pioneers Programme with 5-week international placement (25 September-27 October 2017) in Italy (worked out the project for one of the regions). 
29. Researcher in the Horizon 2020 Euratom project "BRILLIANT - Baltic Region Initiative for Long Lasting Innovative Nuclear Technologies" - coordinated by Lithuanian Energy Institute. Project information: grant agreement ID: 662167, start date 1 July 2015, end date 30 June 2018 (closed project).

\section{Citas aktivitātes}

30. Reviewer's Certificate of EURAM Annual Conference held 19-22 June 2018 at the University of Iceland, Reykjavik. Conference: Entrepreneurship; International Management; Strategic Management.

31. Reviewer's Certificate of EURAM Annual Conference, which was held 21-24 June 2017 at the University of Strathclyde, Glasgow, Scotland, UK. Conference: Innovation; International Management; Strategic Management.

32. Participation in workshop "An introduction to Research Data Management”, 13 April 2016, Digital Curation Centre.

33. KTU 1st International PhD Summer School in Palanga, 23-26 August 2016.

34. Participation in seminar "Take advantage of research data management", 14 October 2015, within the framework of RTU 56th International Scientific Conference.

35. 9 ECTS EU Lifelong learning Program Erasmus Intensive Program "Conducting interdisciplinary research in cross-cultural environment” (2013-1-LV1-ERA10-05531), 29 March-10 April 2014.

36. RTU Professional Development Seminar "Sources of Financing for Innovation and Business", 13 March 2014, Riga, Certificate, series PNI Nr. 1217.

37. Participation in the practical seminar organized by RTU "Pedagogical work at the university" (10 hours), 2014, Certificate No. DS-14/0014. 


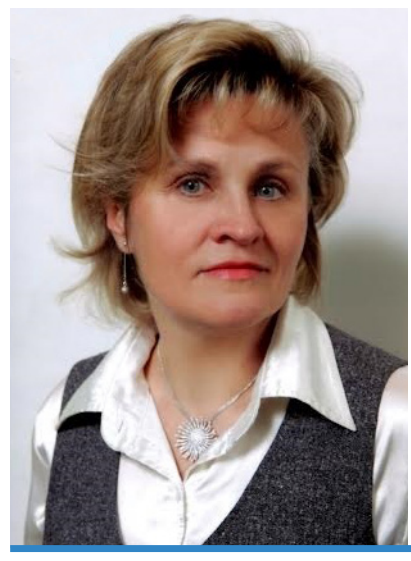

Irēna Vaivode dzimusi 1962. gadā. Latvijas Universitātes Fizikas un matemātikas fakultātē ieguvusi maǵistra grādam pielīdzināto fiziḳa pasniedzēja kvalifikāciju (1986), Rīgas Tehniskās universitātes Rīgas Biznesa skolā - MBA grādu (1998). Piecus gadus bijusi Rīgas Mikroaparātu zinātniskās pētniecības institūta inženiere. Veiksmīgākā vēlāko gadu darbības joma - tūrisma nozare, kur iegūta nozīmīga starptautiskā darba pieredze. Pēdējos gados strādā pedagoǵiskajā darbā un piedalās pētniecības projektos. 